\title{
Influence of Tillage and Crop Rotations in Organic and Conventional Farming Systems on Soil Organic Matter, Bulk Density and Enzymatic Activities in a Short-Term Field Experiment
}

\author{
Marco Pittarello $^{1}$ (D), Nicola Dal Ferro ${ }^{1}\left(\mathbb{D}\right.$, Francesca Chiarini $^{2}\left(\mathbb{D}\right.$, Francesco Morari ${ }^{1}$ (D) and Paolo Carletti ${ }^{1, *(D)}$ \\ 1 Department of Agronomy, Food, Natural Resources, Animals and Environment-DAFNAE, \\ University of Padova, Legnaro, 35020 Padova, Italy; marco.pittarello@unipd.it (M.P.); \\ nicola.dalferro@unipd.it (N.D.F.); francesco.morari@unipd.it (F.M.) \\ 2 Settore Ricerca Agraria, Veneto Agricoltura-Agenzia Veneta per I'Innovazione nel Settore Primario, Legnaro, \\ 35020 Padova, Italy; francesca.chiarini@venetoagricoltura.org \\ * Correspondence: paolo.carletti@unipd.it; Tel.: +39-049-827-2934
}

Citation: Pittarello, M.; Dal Ferro, N.; Chiarini, F.; Morari, F.; Carletti, P. Influence of Tillage and Crop Rotations in Organic and Conventional Farming Systems on Soil Organic Matter, Bulk Density and Enzymatic Activities in a Short-Term Field Experiment. Agronomy 2021, 11, 724. https://doi.org/ 10.3390/agronomy11040724

Academic Editor:

Nikolaos Monokrousos

Received: 25 February 2021

Accepted: 7 April 2021

Published: 9 April 2021

Publisher's Note: MDPI stays neutral with regard to jurisdictional claims in published maps and institutional affiliations.

Copyright: (c) 2021 by the authors. Licensee MDPI, Basel, Switzerland. This article is an open access article distributed under the terms and conditions of the Creative Commons Attribution (CC BY) license (https:/ / creativecommons.org/licenses/by/ $4.0 /)$.
Abstract: Intensive agricultural practices are leading to loss of soil fertility and overexploitation of natural resources which cause nutrients imbalance and further impair ecosystem services. Organic farming $(\mathrm{OF})$, also coupled with minimum tillage and crop rotations, represents one of the strategies to limit this process and maintain soil functions. In a two-year field trial, organic farming practices, including a set of fertilizations combined with crop rotations and association with nitrogen fixing cover crops, were compared. The aim of this research was to assess in the short-term the effects on soil organic carbon, aggregate stability, and soil enzymes activities of using a combination of promising management practices in the delta region of the Po river. Results did not show improvements in organic carbon content and soil aggregate stability. Conversely, enzymatic activities were always significantly higher in OF treatments than the conventional one. Crop rotation and associated legumes were effective in enhancing $\beta$-glucosidase and $P$ fixation through phosphatases activities. The present work suggests that an effective choice of crop species coupled with legumes can enhance biological activity re-starting main mechanisms of microbial development even without a contemporary increase of organic matter.

Keywords: minimum tillage; crop rotation; associated crops; soil organic carbon; soil quality; soil aggregate stabilty

\section{Introduction}

The growing threats of climate change and unsustainable farming systems require a critical review of agronomic strategies needed to secure food production, while mitigating greenhouse gasses (GHGs) emissions, enhancing biodiversity, restoring quality of soil and water resources, and reducing soil erosion [1-3]. In seeking for the best agriculture practice, main issues to be addressed include: (i) depletion of soil organic matter (SOM), (ii) nutrient imbalance, (iii) accelerated soil erosion (with the oncoming risk of desertification), (iv) degradation of soil structure leading to, e.g., crusting and compaction, and (v) decline in soil water and nutrient retention capacities with reduction in resource use efficiency [4].

Organic farming (OF), which is legally defined in European Union (EU), has been proposed as a suitable alternative to conventional farming (CF) [5], with the ambition to drive the transition towards a sustainable food system that enhances the environment. Within the framework of the European Green Deal (European Commission, 2020) [6], the EU aims to achieve the target of $25 \%$ of agricultural land under OF by 2030. Organic farming relies on the SOM management to enhance soil physical, chemical, biological properties, in order to optimize crop production [7]. In OF systems, plant production 
depends almost exclusively on nutrient transformations in soils, since only limited amounts of permitted fertilizers are used [8]. Some direct benefits of consolidating the SOM pools include improvement in soil structure, retention of water and plant nutrients, increase in soil biodiversity, and decrease in risks of soil erosion and the related degradation. Moreover, $\mathrm{OF}$ intends to decrease agriculture diffuse pollution by significantly decreasing the use of mineral fertilizers and consequent aquifer and other water bodies contamination. Important, among numerous ancillary benefits, are increases in input efficiency because of the reduction in losses of water and nutrients from the root zone, increase in the soil and ecosystem resilience, and mitigation of climate change through $\mathrm{CO}_{2}$ sequestration [9]. Thus, in comparison with conventional farming, OF has potential benefits in promoting soil structure formation, enhancing soil biodiversity, alleviating environmental stresses, and improving food quality and safety through increasing SOM [10].

The increase of SOM content leads to more stable aggregates, thus increasing soil physical quality. Six and Paustian [11] have indicated that the key factors of SOM function are location of organic matter within the soil matrix by creating stable organic-mineral complexes. Mechanisms of SOM action to reduce soil vulnerability to structure degradation to both slaking and physical-chemical dispersion are [12]: (i) the formation of a hydrophobic film around soil particles that slows wetting, (ii) the relative increase of the soil micropore fraction $(5-30 \mu \mathrm{m})$, which in turn reduces the internal air pressure and minimizes aggregate disruption [13], (iii) the greater inter-particle cohesion [14]. In contrast, there is still debate on to what extent fertilization types and levels, i.e., organic fertilization or crop residues, combined with growing different crops in rotation may affect the aggregate stability, having most likely changed the microbial-derived soil structure cohesion that would affect the aggregate stability [15].

Hydrolytic enzymes make nutrients available to plants and soil microorganisms from a wide array of complex substrates occupying a pivotal role in catalyzing reactions associated with organic matter decomposition and nutrient cycling. These enzymes are influenced by a wide range of soil properties such as $\mathrm{pH}$, organic matter content, soil texture, which, in turn, are altered by management [16]. Enzyme activities have been suggested as soil indicators suitable for use in the evaluation of the degree of alteration of soils in both natural and anthropic agroecosystems [17]. Some research has already suggested the positive effects of farming practices on soil enzyme activities under Mediterranean [18] and temperate climate [19].

Furthermore, crop species influence microbial populations in the rizosphere: for example, wheat, ryegrass, bentgrass, and clover roots exudates increase different kinds of microbial species, indicating a clear discrimination between the carbon sources utilized by microbial communities from the different plant rhizospheres [20]. Miller et al. [21] found significant differences among the rhizosphere bacterial community of wheat, maize, and grass, while Houlden et al. [22] showed clear shifts in rhizosphere microbial communities depending on developmental stage in wheat, pea, and sugar beet.

The aim of this research was to assess in the short-term the differences induced by conventional and organic farming practices coupled with reduced tillage, crop rotation, and organic amendments in the delta region of the Po river.

In this context, the SOM content and characteristics, specific enzyme activities, and soil aggregate stability were selected as possible indicators for soil quality assessment [23] to evaluate the implications of different management practices and of a conversion into organic farming.

\section{Materials and Methods}

\subsection{Study Area}

A field trial was conducted in the years 2008-2009 at the Horticultural Experimental Centre "Po di Tramontana" in Rosolina (Italy) located on the Po delta area of the Veneto Region $\left(45^{\circ} 04^{\prime} 04^{\prime \prime} \mathrm{N} 12^{\circ} 15^{\prime} 46^{\prime \prime} \mathrm{E}\right)$. The local climate is classified as temperate suboceanic [24] with a mean annual rainfall of $721 \mathrm{~mm}, 76$ rainy days per year (30-years average). The 
temperature reaches minimum values in January $\left(0.7^{\circ} \mathrm{C}\right.$, on average $)$ and maximum values in July and August $\left(29.0^{\circ} \mathrm{C}\right.$, on average). Air relative humidity ranges from 60 to $97 \%$.

The characterization of the soil initial conditions for the experiment is reported in Table 1. The soil was a fairly homogeneous sandy loam classified as Calcaric Gleysol [25] characterized by a sub-neutral/alkaline $\mathrm{pH}$, low SOC content, and low CEC.

Table 1. Soil characterization.

\begin{tabular}{|c|c|c|c|c|c|c|c|}
\hline $\begin{array}{c}\text { Soil } \\
\text { Parameters }\end{array}$ & Sand & Clay & Silt & EC & $\mathrm{pH}$ & CEC & SOC \\
\hline Management & & $\%$ & & $\mathrm{mS} \mathrm{cm}^{-1}$ & & mmol $100 \mathrm{~g}^{-1}$ & $\mathrm{~g} \mathrm{~kg}^{-1}$ \\
\hline Conv WR & $66.25 \pm 4.32$ & $16.75 \pm 1.49$ & $17.00 \pm 4.35$ & $370.00 \pm 21.68$ & $7.62 \pm 0.48$ & $13.47 \pm 0.61$ & $6.10 \pm 1.04$ \\
\hline Org SGR + C & $64.33 \pm 5.36$ & $19.67 \pm 1.20$ & $16.00 \pm 4.16$ & $463.00 \pm 81.10$ & $7.76 \pm 0.03$ & $14.60 \pm 0.50$ & $12.96 \pm 1.51$ \\
\hline Org SGR & $73.00 \pm 11.35$ & $16.67 \pm 7.20$ & $10.33 \pm 4.25$ & $543.00 \pm 138.62$ & $7.70 \pm 0.00$ & $13.47 \pm 3.18$ & $10.46 \pm 2.33$ \\
\hline Org PBF + P & $64.00 \pm 5.50$ & $20.00 \pm 2.51$ & $14.67 \pm 1.76$ & $458.33 \pm 93.68$ & $7.67 \pm 0.09$ & $14.83 \pm 1.16$ & $11.39 \pm 2.84$ \\
\hline \multirow[t]{3}{*}{ Org PBF } & $70.33 \pm 11.14$ & $13.67 \pm 4.91$ & $16.00 \pm 6.93$ & $445.33 \pm 54.01$ & $7.70 \pm 0.10$ & $11.90 \pm 2.14$ & $9.76 \pm 3.43$ \\
\hline & exch. Ca & exch. $\mathrm{Mg}$ & exch. $\mathrm{Na}$ & exch. K & total $\mathrm{N}$ & ass. $\mathrm{P}$ & $\mathrm{CaCO}_{3}$ \\
\hline & & & & $\mathrm{g} \mathrm{kg}^{-1}$ & & & \\
\hline Conv WR & $3.07 \pm 0.38$ & $0.25 \pm 0.05$ & $0.21 \pm 0.03$ & $0.41 \pm 0.17$ & $0.50 \pm 0.13$ & $0.11 \pm 0.03$ & $0.02 \pm 0.01$ \\
\hline Org SGR + C & $4.05 \pm 1.05$ & $0.32 \pm 0.05$ & $0.27 \pm 0.05$ & $0.38 \pm 0.02$ & $0.78 \pm 0.34$ & $0.11 \pm 0.02$ & $0.02 \pm 0.06$ \\
\hline Org SGR & $4.93 \pm 1.94$ & $0.29 \pm 0.04$ & $0.23 \pm 0.04$ & $0.25 \pm 0.05$ & $0.88 \pm 0.16$ & $0.09 \pm 0.01$ & $0.02 \pm 0.08$ \\
\hline Org PBF + P & $3.87 \pm 0.84$ & $0.29 \pm 0.04$ & $0.17 \pm 0.02$ & $0.35 \pm 0.01$ & $1.10 \pm 0.23$ & $0.10 \pm 0.03$ & $0.02 \pm 0.00$ \\
\hline Org PBF & $4.32 \pm 0.73$ & $0.34 \pm 0.06$ & $0.24 \pm 0.05$ & $0.32 \pm 0.02$ & $1.1 \pm 0.21$ & $0.09 \pm 0.01$ & $0.03 \pm 0.01$ \\
\hline
\end{tabular}

Soil texture and chemistry. The samples were collected in January 2008 to characterize the soil before the experiment. All values are reported with own standard error. EC: electric conductivity; CEC: cation exchange capacity; SOC: soil organic carbon; Ass. P: assimilable phosphorus.

\subsection{Experimental Design}

The experiment was conducted on plots, consisting each of $240 \mathrm{~m}^{2}(8 \mathrm{~m} \times 30 \mathrm{~m})$, which were conducted in accordance to organic EC Regulation since 2000. Experimental design consisted of one conventional (Conv) and four organic treatments (Org) in a randomized block design with three replicates.

In the two years preceding the experiment (2006 and 2007), the area was managed as follows: the Conv plots were left uncultivated for 3 out of 4 semesters and for the remaining semester cultivated with radicchio (Chicorium intybus L., 1753); the Org plots were uncultivated for 2 semesters, then cultivated again with wheat (Triticum aestivum L.) and cabbage (Brassica oleracea var. cauliflower) and intercropped with clover (Trifolium repens L.).

Conv was ploughed at $35 \mathrm{~cm}$ depth with crop residues incorporation followed by seedbed preparation with disk arrow $(<15 \mathrm{~cm}$ depth), then cultivated with winter wheat and rapeseed (Brassica napus L., 1753) (Conv WR) and amended with $36 \mathrm{tha}^{-1}$ of organomineral fertilizers (Spiga d'oro produced by Unimer, Milano, Italy NPK 1:2.25:0), $50 \mathrm{~kg} \mathrm{ha}^{-1}$ of urea, and $200 \mathrm{~kg} \mathrm{ha}^{-1}$ of ammonium sulfate. Org was managed according to minimum tillage practices consisting in surface chiseling $(20 \mathrm{~cm})$ only. Cultivation treatments under comparison were: (1) a cropping sequence of sorghum (Sorghum vulgare Pers.), garlic (Allium sativum L.), and radicchio (hereafter labeled "Org SGR"); (2) the same cropping sequence as before plus clover (Trifolium repens $\mathrm{L}$.) as associated intercrop (hereafter labeled Org "SGR + C"); (3) a pumpkin (Cucurbita maxima Duchesne, 1786), barley (Hordeum vulgare L.), and fennel (Foeniculum vulgare L., 1753) rotation (hereafter labeled "Org PBF"); (4) finally the fourth cropping sequence was the same as "Org PBF" with the addition of pea (Pisum sativum L., 1753) as associated intercrop ("Org PBF + P"). Fertilizations in Org consisted in liquid and pelleted organic amendments supplied as follows: in Org SGR + C, $1.5 \mathrm{tha}^{-1}$ of Borlanda produced by La Mediterranea, Budrio, Italy (liquid residues from sugarbeet wort alcoholic fermentation NPK 3:0:6) in September 2008 and $0.25 \mathrm{t} \mathrm{ha}^{-1}$ of Orgazot produced by AGM, Castelnuovo di Sotto, Italy (from lyophilized blood $\mathrm{N}=14 \%$ ) in August 2009; in Org PBF + P, the dose was doubled in September 2008 (3.0 t ha ${ }^{-1}$ Borlanda, NPK 3:0:6) while was maintained at $0.25 \mathrm{t} \mathrm{ha}^{-1}$ Orgazot $(\mathrm{N}=14 \%)$ in August 2009. In both Org SGR and Org PBF amendments were equally distributed as follows: $2.5 \mathrm{t} \mathrm{ha}^{-1}$ of 
Bio-rex produced by Italpollina, Rivoli Veronese, Italy (pelleted manure, $\mathrm{N}=2.8 \%, \mathrm{C} / \mathrm{N}=$ 13) in May 2008, $3.0 \mathrm{t} \mathrm{ha}^{-1}$ Borlanda (NPK 3:0:6) in September 2008, $6 \mathrm{t} \mathrm{ha}^{-1}$ of Organfertil produced by Compo Italia, Cesano Maderno, Italy (pelleted $\mathrm{N}=1 \% ; \mathrm{C} / \mathrm{N}=25$ ) in July $2009,0.25 \mathrm{t} \mathrm{ha}^{-1}(\mathrm{~N}=14 \%)$ in August 2009 (Table 2).

Table 2. Experimental setup.

\begin{tabular}{|c|c|c|c|c|c|c|c|c|c|}
\hline \multirow[t]{2}{*}{ Management } & \multicolumn{4}{|c|}{ Turn Over and Cover/Intercropping } & \multicolumn{4}{|c|}{ Manuring } & \multirow[t]{2}{*}{$\begin{array}{l}\text { Tilling } \\
\text { Depth }\end{array}$} \\
\hline & $\begin{array}{c}\text { 1st Sem } \\
2008 \\
\end{array}$ & $\begin{array}{c}\text { 2nd Sem } \\
2008\end{array}$ & $\begin{array}{c}\text { 1st Sem } \\
2009\end{array}$ & $\begin{array}{c}\text { 2nd Sem } \\
2009\end{array}$ & $\begin{array}{c}\text { Organo Mineral } \\
\text { NPK }\end{array}$ & Urea & $\left(\mathrm{NH}_{4}\right)_{2} \mathrm{SO}_{4}$ & $\begin{array}{c}\text { Organic } \\
\text { Amendement }\end{array}$ & \\
\hline & & & & & tha $a^{-1}$ & \multicolumn{2}{|c|}{ kg ha $^{-1}$} & tha $a^{-1}$ & $\mathrm{~cm}$ \\
\hline CONV WR & $\mathrm{R}$ & WR & WR & $\mathrm{W}$ & 36 & 50 & 200 & 0 & $35+15$ \\
\hline $\begin{array}{c}\text { Org SGR + C } \\
\text { Org SGR } \\
\text { Org PBF + P } \\
\text { Org PBF }\end{array}$ & $\begin{array}{l}\mathrm{CS} \\
\mathrm{S} \\
\mathrm{Pu} \\
\mathrm{Pu}\end{array}$ & $\begin{array}{c}\mathrm{CS} / \mathrm{G} \\
\mathrm{S} / \mathrm{G} \\
\mathrm{Pu} / \mathrm{BP} \\
\mathrm{Pu} / \mathrm{B}\end{array}$ & $\begin{array}{c}\mathrm{CG} \\
\mathrm{G} \\
\mathrm{BP} \\
\mathrm{B}\end{array}$ & $\begin{array}{c}\text { CG/Rad } \\
\text { G/Rad } \\
\text { F } \\
\text { F }\end{array}$ & 0 & 0 & 0 & $\begin{array}{c}1.5+0.25 \\
2.5+3+6+0.25 \\
3+0.25 \\
2.5+3+6+0.25\end{array}$ & 20 \\
\hline
\end{tabular}

$\mathrm{B}=$ barley; $\mathrm{C}=$ clover; $\mathrm{F}$ = fennel; $\mathrm{G}=$ garlic; $\mathrm{P}$ = pea; $\mathrm{Pu}=$ pumpkin; $\mathrm{R}=$ rapeseed; Rad = radicchio; $\mathrm{S}$ = sorghum; $\mathrm{W}=$ wheat. The bar " /" indicates presence of crops in the same semester but not associated. Organic amendments were distributed in several times in different amounts. Conventional tillage was ploughed and chiseled in two steps, at different depths.

Treatments including clover and pea were supplied with a lower amount of $\mathrm{N}$ fertilizer due to the $\mathrm{N}$ fixing action of these species.

\subsection{Crops Yield of the Experimental Fields}

The yield achieved in each Org management was recorded for the two-year experiment and total production is reported in Table 3. Sorghum was harvested in May 2008; garlic in October 2008; radicchio in August 2009; pumpkin in May 2008; barley and pea in November 2008; and fennel in August 2009. CONV productivity was of $2.2 \mathrm{t} \mathrm{ha}^{-1}$ rapeseed harvested in July 2008; $6.0 \mathrm{t} \mathrm{ha}^{-1}$ of wheat were harvested in July 2009.

Table 3. Crops yield of Org managements.

\begin{tabular}{cccccccc}
\hline & Sorghum & Garlic & Radicchio & Pumpkin & Barley & Pea & Fennel \\
\hline & & & t ha $^{-1}$ & & - & - \\
Org SGR + C & 13.03 & 1.11 & 13.55 & - & - & - & - \\
Org SGR & 28.72 & 3.14 & 13.35 & - & 1.90 & 0.78 & - \\
Org PBF + P & - & - & - & 22.17 & 1.87 & 19.84 \\
Org PBF & - & - & - & 22.03 & \\
\hline
\end{tabular}

The data set shows the whole production of the entire experimental period (2008 and 2009). Clover biomass was not considered.

\subsection{Soil Sampling}

Disturbed soil samples were collected in the top $25 \mathrm{~cm}$ layer before starting the experiment (January 2008) for preliminary analyses reported in Table 1. Sampling on January 2008 was performed for initial soil characterization (main soil physical-chemical properties). During March, July, and November for both 2008 and 2009 years for a total of six sampling dates, samples for SOM and enzyme activities were collected. Field-moist bulk soil samples were split into two subsamples. One soil subsample was sieved at $2 \mathrm{~mm}$ and stored at $2{ }^{\circ} \mathrm{C}$ for enzyme activities analyses, while the other was used for chemical and physical analyses. Soil samples from each plot were composed of five subsamples that were bulked to obtain a sample of about $3 \mathrm{~kg}$. Sampling involved the central area of the plots excluding a 2-m edge to avoid soil movement effects [26]. Additionally, a total of 30 undisturbed soil cores, $8 \mathrm{~cm}$ diameter, one per plot each year, in November 2008 and 2009, were taken from the topsoil $(0-25 \mathrm{~cm})$ for bulk density calculation.

\subsection{Physical-Chemical Parameters}

Undisturbed samples were weighed and a fraction was oven-dried at $105^{\circ} \mathrm{C}$ for $24 \mathrm{~h}$ to calculate bulk density according to the core method [27]. The $\mathrm{pH}$ was measured potentio- 
metrically on pulverized samples by adding deionized water (1:2.5 w/v, dry weight basis). The electrical conductivity (EC) was potentiometrically determined after water extraction $(2: 5 w / v)$ and filtration through Whatman filter N. 2 paper. Particle size analysis was performed according to the hydrometer method, using sodium hexametaphosphate as a dispersant (Gee and Bauder 1986). Exchangeable bases, including calcium (Ca), magnesium $(\mathrm{Mg})$, potassium $(\mathrm{K})$, and sodium $(\mathrm{Na})$, were extracted using barium chloride as reported in [28], and their concentrations were determined by inductively coupled plasma-optical emission spectroscopy (ICP-OES) on a SPECTRO CIROS (Spectro Analytical Instruments, Kleve, Germany). Cation exchange capacity CEC was calculated as reported in [29]. Plant available phosphorus (P) was calculated using the Olsen method [30]. Carbonate content $\left(\mathrm{CaCO}_{3}\right)$ was determined by the volumetric calcimeter method [31].

Soil organic C (SOC) was determined by a wet oxidation titration procedure using an acid dichromate system [32].

Total $\mathrm{N}$ was measured on air-dried $0.5 \mathrm{~mm}$ sieved samples using the flash combustion method (CNS Elemental Analyzer, Vario Max, Elementar Inc., Langenselbold, Germany).

For particle size distribution determination, the standard pipette method was used as described by USDA-NRCS (2004) [33]

\subsection{Soil Organic Matter Parameters}

Humic substances were extracted from $2 \mathrm{~mm}$-sieved, air-dried samples with $0.1 \mathrm{M}$ $\mathrm{KOH}(1: 10 w / v)$ at room temperature for $16 \mathrm{~h}$ under an $\mathrm{N}_{2}$ atmosphere and freed from the suspended material by centrifugation at 7.000 $\times g$ for $20 \mathrm{~min}$ and filtration on Whatman (Whatman, Maidstone, England) $\mathrm{N}^{\circ} 42$ filter paper. Organic carbon content was assayed by dichromate oxidation [32]. Molecular-weight distribution and gel-permeation chromatography of each humic extract was carried out on a Sephadex G-100 gel packed in a $70 \mathrm{~cm} \times$ $1.6 \mathrm{~cm}$ Pharmacia column (Pharmacia, Uppsala, Sweden) as reported in Cardinali et al. [34]. The gel packing solution and the eluant were $20 \mathrm{mM} \mathrm{Na}{ }_{2} \mathrm{~B}_{4} \mathrm{O}_{7}$. The apparent molecular weight of the fractions was $>100,10-100$, and $<10 \mathrm{kDa}$. The column calibration was based on standard kit for molecular weights (Sigma-Aldrich Gel Filtration Molecular Weight Markers MWGF200). All chemical determinations were performed in triplicate.

\subsection{Enzyme Activities}

Enzyme activities were determined on fresh moist sieved ( $<2 \mathrm{~mm}$ ) soils within 10 days from the collection of the samples. Triplicates were performed for each activity assay. Control assays were performed in all cases, except for dehydrogenase, by adding the substrate after the reaction was stopped and before filtration of the soil suspension. All data were corrected to soil dry weight by means of soil moisture content data.

Urease activity (E.C. 3.5.1.5) was assayed as described by Kandeler and Gerber [35] using $0.08 \mathrm{M}$ urea as substrate while the samples were incubated at $30{ }^{\circ} \mathrm{C}$ for $2 \mathrm{~h} . \mathrm{N}-\alpha-$ benzoyl-L-argininamide (BAA) hydrolyzing protease activity was determined in $0.1 \mathrm{M}$ phosphate buffer at $\mathrm{pH} 7 ; 0.03 \mathrm{MBAA}$ was used as substrate [36]. The sample was incubated at $40^{\circ} \mathrm{C}$ for $2 \mathrm{~h}$. The resulting suspensions were filtered, and filtrates analyzed for ammonia by the following colorimetric procedure. One milliliter of filtrate was diluted to $10 \mathrm{~mL}$ with distilled $\mathrm{H}_{2} \mathrm{O}$ and, successively, $5 \mathrm{~mL}$ Na salicylate solution $(100 \mathrm{~mL}$ sodium nitroprussiate $1.2 \mathrm{~g} \mathrm{~L}^{-1}, 100 \mathrm{~mL}$ Na salicylate $17 \mathrm{~g} \mathrm{~L}^{-1}$, and $100 \mathrm{~mL}$ distilled $\mathrm{H}_{2} \mathrm{O}$ mixed and the moment of use) and $2 \mathrm{~mL} \mathrm{10 \%} \mathrm{Na} \mathrm{dichloroisochanurate} \mathrm{were} \mathrm{added.} \mathrm{Solutions} \mathrm{were} \mathrm{incubated} \mathrm{for}$ $30 \mathrm{~min}$ at room temperature and solution absorbance measured spectrophotometrically at $600 \mathrm{~nm}$ [35]. Urease and protease activities were determined as $\mu \mathrm{g} \mathrm{NH}_{4}^{+} \mathrm{g}^{-1}$ dry soil h $\mathrm{h}^{-1}$ released in the hydrolysis reaction.

Dehydrogenase activity was determined following a modification of Masciandaro et al. [37]. Soil was mixed with $0.2 \mathrm{~mL}$ of $0.4 \%(7.91 \mathrm{mM})$ 2-p-iodo-phenyl-3p-nitrophenyl-5-phenyltetrazolium chloride (INT) solution (in distilled water, $w / v$ ). The control was the soil treated with distilled water $(0.2 \mathrm{~mL})$, instead of INT. Soils were incubated for $20 \mathrm{~h}$ at $20^{\circ} \mathrm{C}$ in darkness; $\mathrm{pH}$ values did not vary during the incubation time. The 
iodonitrotetrazolium formazan (INTF) formed by the reduction of INT was extracted by adding $10 \mathrm{~mL}$ of a mixture of 1:1.5 tetrachloroethylene and acetone; then, the soil mixture was vigorously shaken by hand for $1 \mathrm{~min}$ and finally filtered through a Whatman no. 41 filter paper. The INTF concentration was measured spectrophotometrically at $490 \mathrm{~nm}$, and the results were expressed as $\mu \mathrm{g}$ INTF $\mathrm{g}^{-1}$ dry soil $\mathrm{h}^{-1}$.

Alkaline phosphatase (EC 3.1.3.1 orthophosphoric- monoester phosphohydrolase, alkaline optimum), phosphodiesterase (EC 3.1.4.1 orthophosphoric diester phosphohydrolase), and $\beta$-glucosidase (EC 3.2.1.21, $\beta$-D-glucoside glucohydrolase) activities were determined according to official Italian methods for soil analysis. To measure alkaline phosphatase activity, four milliliters of modified universal buffer (MUB), $\mathrm{pH} 11$, and $1 \mathrm{~mL}$ of substrate p-nitrophenyl phosphate (PNPP) $0.025 \mathrm{M}$ were added to $1 \mathrm{~g}$ of soil and incubated at $37^{\circ} \mathrm{C}$ for $1 \mathrm{~h}$. The reaction was stopped by adding $1 \mathrm{~mL} 0.5 \mathrm{M} \mathrm{CaCl}_{2}$ and $4 \mathrm{~mL} 0.5 \mathrm{M}$ $\mathrm{NaOH}$.

Phosphodiesterase activity was determined following Browman and Tabatabai [38]. Briefly, $4 \mathrm{~mL} 0.05 \mathrm{M}$ TRIS-buffer $\mathrm{pH} 8$ and $1 \mathrm{~mL}$ bis-p-nitrophenyl phosphate $0.005 \mathrm{M}$ were added to $1 \mathrm{~g}$ of soil and incubated at $37^{\circ} \mathrm{C}$ for $1 \mathrm{~h}$. The reaction was stopped by adding $1 \mathrm{~mL} 0.5 \mathrm{M} \mathrm{CaCl}_{2}$ and $4 \mathrm{~mL} 0.1 \mathrm{M}$ TRIS-NaOH pH 12 buffer.

For the determination of $\beta$-glucosidase activity, four milliliters of modified universal buffer (MUB), $\mathrm{pH}$ 6, and $1 \mathrm{~mL}$ of substrate p-nitrophenyl-b-D-glucopyranoside (PNG) $0.025 \mathrm{M}$ were added to $1 \mathrm{~g}$ of soil and incubated at $37^{\circ} \mathrm{C}$ for $1 \mathrm{~h}$ The reaction was stopped by adding $1 \mathrm{~mL} 0.5 \mathrm{M} \mathrm{CaCl}_{2}$ and $4 \mathrm{~mL} 0.1 \mathrm{M}$ TRIS-NaOH pH 12 buffer [39].The p-nitrophenol $(\mathrm{pNP})$ formed in alkaline phosphatase, phosphodiesterase, and $\beta$-glucosidase activities was determined by spectrophotometry at $400 \mathrm{~nm}$ and reported as $\mu \mathrm{g}$ p-nitrophenol (pNP) $\mathrm{g}^{-1}$ dry soil $\mathrm{h}^{-1}$.

The fluorescein diacetate hydrolase (FDAH) activity was assessed as described by Adam and Duncan [40]. A 2-g soil sample was shaken for $15 \mathrm{~min}$ with $15 \mathrm{~mL}$ of $60 \mathrm{mM}$ potassium phosphate $\mathrm{pH} 7.6$ buffer and with $0.2 \mathrm{~mL}$ of $1000 \mu \mathrm{g} \mathrm{mL} \mathrm{mL}^{-1}$ FDA solution for $20 \mathrm{~min}$ at $30^{\circ} \mathrm{C} .15 \mathrm{~mL}$ of 2:1 chloroform/methanol solution was added, and the contents shaken thoroughly by hand before filtration (Whatman, No 2). The absorbance was measured spectrophotometrically at $490 \mathrm{~nm}$ on the filtrate. The concentration was expressed in $\mathrm{mg}$ fluorescein released $\mathrm{g}^{-1}$ dry soil $\mathrm{h}^{-1}$.

\subsection{Soil Aggregate Stability}

Samples were air-dried. During the drying operation, the bulk soil was broken along natural fissures into small pieces by gentle hand manipulation [40]. Once dried, the 1$2 \mathrm{~mm}$ aggregate fraction was separated and subjected to $200-\mu \mathrm{m}$ wet sieving, applying vertical shaking for $30 \mathrm{~min}$ with a frequency of 30 oscillations per minute (900 oscillations in total) at a $3 \mathrm{~cm}$ amplitude [41]. The material was then carefully transferred to a second beaker by a washing flask and oven-dried at $105{ }^{\circ} \mathrm{C}$ to constant mass. The coarse sand (200-2000 $\mu \mathrm{m}$ ) content was determined by adding $25 \mathrm{~mL}$ of a solution containing $40 \mathrm{~g}$ sodium hexametaphosphate and $10 \mathrm{~g}$ sodium carbonate in $1 \mathrm{~L}$ to each dry sample (about $7 \mathrm{~g}$ ), allowing to stand for $24 \mathrm{~h}$, washing (with demineralized water) on a sieve $(200 \mu \mathrm{m})$, and oven-drying the material retained.

The wet aggregate stability index (WASI) was calculated as specified in Dal Ferro et al. [13]:

$$
\mathrm{WASI}=\frac{\mathrm{WSA}-\mathrm{W}_{\text {sand }}}{\mathrm{W}_{\mathrm{agg}}-\mathrm{W}_{\text {sand }}}
$$

where WSA is the dry mass of water stable aggregates $>200 \mu \mathrm{m}, \mathrm{W}_{\text {agg }}$ the total dry mass of the sieved aggregates, and $W_{\text {sand }}$ the dry mass of coarse sand particles measured after dispersion.

Before wet sieving, soil aggregates were subjected to fast wetting obtained by immersing $10 \mathrm{~g}$ soil aggregates in deionized water for $10 \mathrm{~min}$ to simulate the effect of heavy rain storms [42]. To distinguish slaking from physical-chemical dispersion, before fast wetting soil aggregates were subjected to: (i) no pretreatment (WSA), (ii) pretreatment 
with benzene (BSA = benzene stable aggregates) to coat the aggregates and emphasize the hydrophobic nature of SOM [12], (iii) pretreatment with ethanol (ASA = alcohol stable aggregates) to test the wet mechanical cohesion by substituting air with a polar liquid before energy is applied [43]. Immersion of ethanol-pretreated soil aggregates in water minimizes slaking of dried soil aggregates and emphasizes the resistance of soil aggregates to dissolution and the dispersive action of water.

\subsection{Statistical Analyses}

One-way ANOVA with repeated measures were performed in order to compare treatments among the sampling periods; for those parameters that have available less than 3 sampling times, a two-way ANOVA was performed, including the sampling time as a fixed factor. Duncan test was performed for post-hoc comparisons. Paired $T$ test was performed to compare enzymatic activities between the same period of different years (e.g., March 2008 vs. March 2009). Levene and Mauchly's tests were applied to check homoscedasticity and sphericity, respectively, to ensure that assumptions of the model were met as recommended in Field [44]. Pearson's correlation was performed to test correlations between organic carbon content and soil stability indexes. All these procedures were performed by IBM SPSS 26.0.

A canonical discriminant analysis (CDA) was performed by SAS software (SAS Institute, 2004) to determine which variables best predicts group membership and to visualize the data by grouping the variables in one or more axes [34]. The analysis selects a limited set of discriminant functions that best describe the separation of the studied plots. A stepwise procedure was also applied to choose the set of variables characterized by the highest correlation with the factor and assess the relative importance of each independent variable. The consistency and overall robustness of the separation was evaluated by the Mahalanobis quadratic distance, an index that measures the squared distances between the centroids of each cloud, thus reflecting the actual separation between the different managements. The Wilks Lambda, performed to evaluate the quality of the multivariate statistics, shows significant differences among population means.

\section{Results}

\subsection{Soil Physical Parameters}

Bulk density (Table 4) showed significant differences only in 2008 between Org PBF and the other treatments. It was also noted a convergence to a narrow range of bulk density values in 2009 compared to the previous year. Although this behavior appears clear, from a statistically point of view, there is no evidence about a significant effect of the factor time.

Table 4. Bulk density.

\begin{tabular}{|c|c|c|}
\hline Bulk Density & 2008 & 2009 \\
\hline Management & \multicolumn{2}{|c|}{$\mathrm{g} \mathrm{cm}^{-3}$} \\
\hline Conv WR & $1.60 \pm 0.05^{a}$ & $1.54 \pm 0.04^{a}$ \\
\hline Org SGR + C & $1.55 \pm 0.08^{a}$ & $1.49 \pm 0.05^{a}$ \\
\hline Org SGR & $1.48 \pm 0.00^{\mathrm{a}}$ & $1.49 \pm 0.06^{\mathrm{a}}$ \\
\hline Org $\mathrm{PBF}+\mathrm{P}$ & $1.63 \pm 0.02^{\mathrm{a}}$ & $1.46 \pm 0.06^{a}$ \\
\hline \multirow[t]{2}{*}{ Org PBF } & $1.33 \pm 0.04^{b}$ & $1.45 \pm 0.08^{a}$ \\
\hline & $\mathrm{F}$ & $p$ \\
\hline Time & 0.84 & 0.37 \\
\hline Management & 3.71 & 0.02 * \\
\hline Time * Management & 1.98 & 0.13 \\
\hline
\end{tabular}

Evolution through the experimental period. Values are reported with their standard errors. ${ }^{a-b}$ different letters mean significant differences among managements within the same year. ${ }^{*} p<0.05$ values indicate significant differences. 
Wet aggregate stability indexes (WASI) (Table 5A) pretreated with ethanol (ASA) led to the highest aggregate stability in both years, showing a $48.6 \%$ biennial mean value, while benzene pretreatment (BSA) and non-pretreated aggregates (WSA) showed lower and similar values, respectively $8.1 \%$ and $12.8 \%$. The aggregate structure was not degrading significantly in the different years, despite a tendency to lower WASI was observed in 2009 than 2008, regardless the tested treatments.

Table 5. Evolution of stability indexes (WASI), humic fractions, and humic carbon contents.

\begin{tabular}{|c|c|c|c|c|c|c|c|}
\hline A WASI & WSA 2008 & WSA 2009 & BSA 2008 & BSA 2009 & ASA 2008 & ASA 2009 & \\
\hline Management & & & & \% & & & \\
\hline Conv WR & $3.3 \pm 1.0^{\mathrm{b}}$ & $2.5 \pm 0.6^{b}$ & $3.6 \pm 1.4^{b}$ & $4.0 \pm 2.0^{a}$ & $29.9 \pm 7.3^{b}$ & $14.3 \pm 4.4^{\mathrm{b}}$ & \\
\hline Org SGR + C & $13.4 \pm 1.9^{a b}$ & $15.4 \pm 3.6^{\mathrm{ab}}$ & $11.2 \pm 2.2^{\mathrm{a}}$ & $6.4 \pm 1.4^{\mathrm{a}}$ & $62.8 \pm 7.4^{\mathrm{a}}$ & $44.8 \pm 8.5^{a}$ & \\
\hline Org SGR & $19.1 \pm 7.3^{a}$ & $13.4 \pm 5.5^{\mathrm{ab}}$ & $10.8 \pm 2.3^{a}$ & $5.1 \pm 1.8^{\mathrm{a}}$ & $60.3 \pm 6.8^{a}$ & $46 \pm 9.8^{a}$ & \\
\hline Org PBF + P & $16.3 \pm 3.3^{\mathrm{a}}$ & $16.9 \pm 1.7^{\mathrm{b}}$ & $11.6 \pm 0.6^{a}$ & $8.9 \pm 2^{a}$ & $65.5 \pm 1.9^{a}$ & $48.5 \pm 7.8^{a}$ & \\
\hline Org PBF & $10.7 \pm 3.1 \mathrm{ab}$ & $17.3 \pm 6.7^{\mathrm{b}}$ & $11.8 \pm 3.5^{\mathrm{a}}$ & $7.5 \pm 2^{\mathrm{a}}$ & $\begin{array}{c}65 \pm 8.4^{\mathrm{a}} \\
\mathrm{F}\end{array}$ & $49.1 \pm 11.3^{\mathrm{a}}$ & \\
\hline Time & 0.05 & $\begin{array}{l}p \\
0.82\end{array}$ & 7.19 & $\begin{array}{c}p \\
0.01\end{array} *$ & 11.17 & $\begin{array}{c}p \\
0.003\end{array} *$ & \\
\hline Management & 5.14 & $0.004 *$ & 3.75 & $0.02 *$ & 9.03 & 0.00 * & \\
\hline Time * Management & 0.64 & 0.64 & 0.79 & 0.54 & 0.016 & 0.999 & \\
\hline $\begin{array}{c}\text { B Soil Organic } \\
\text { Carbon }\end{array}$ & March 2008 & July 2008 & November 2008 & March 2009 & July 2009 & November 2009 & $M$ Average \\
\hline Management & & & & $\mathrm{g} \mathrm{kg}^{-1}$ & & & \\
\hline Conv WR & $6.8 \pm 0.9$ & $6.0 \pm 0.1$ & $4.8 \pm 0.7$ & $4.6 \pm 0.5$ & $4.2 \pm 0.5$ & $4.8 \pm 0.7$ & $5.2 \pm 0.4^{b}$ \\
\hline Org SGR + C & $11.0 \pm 1.7$ & $10.4 \pm 1.3$ & $10.8 \pm 1.7$ & $10.7 \pm 1.5$ & $9.9 \pm 1.1$ & $10.1 \pm 1.8$ & $10.5 \pm 0.2^{a}$ \\
\hline Org SGR & $9.2 \pm 1.8$ & $8.6 \pm 1.4$ & $9.2 \pm 1.4$ & $9.4 \pm 1.9$ & $9.2 \pm 1.9$ & $9.6 \pm 1.3$ & $9.2 \pm 0.1^{a}$ \\
\hline Org PBF + P & $10.3 \pm 1.3$ & $9.4 \pm 1.3$ & $9.8 \pm 1.5$ & $10.4 \pm 1.7$ & $10.7 \pm 1.5$ & $10.0 \pm 1.6$ & $10.1 \pm 0.2^{a}$ \\
\hline Org PBF & $11.0 \pm 1.3$ & $8.8 \pm 0.9$ & $9.8 \pm 1.1$ & $10.0 \pm 1.4$ & $9.8 \pm 0.9$ & $9.2 \pm 0.9$ & $9.8 \pm 0.3^{a}$ \\
\hline T Average & $9.5 \pm 0.7^{a}$ & $8.5 \pm 0.6^{a}$ & $8.6 \pm 0.8^{a}$ & $8.7 \pm 0.8^{a}$ & $8.5 \pm 0.8^{a}$ & $8.5 \pm 0.7^{a}$ & \\
\hline Time & $\begin{array}{l}\mathrm{F} \\
3.808\end{array}$ & $\begin{array}{c}p \\
0.005 *\end{array}$ & & & & & \\
\hline Management & 3.487 & $0.045 *$ & & & & & \\
\hline Time * Management & $\begin{array}{l}0.407 \\
1.978\end{array}$ & 0.024 * & & & & & \\
\hline C Humic Fractions & F1 March 2008 & F1 November 2009 & F2 March 2008 & F2 November 2009 & F3 March 2008 & F3 November 2009 & \\
\hline Management & & & & $\%$ & & & \\
\hline Conv WR & $25.6 \pm 2.4^{\mathrm{a}}$ & $17.6 \pm 0.5^{\mathrm{ab}}$ & $52.9 \pm 0.6^{a}$ & $67.5 \pm 1.2^{a}$ & $21.5 \pm 2.2^{b}$ & $14.8 \pm 0.6^{\mathrm{b}}$ & \\
\hline Org SGR + C & $29.9 \pm 3.2^{a}$ & $17.6 \pm 0.9^{a b}$ & $48.0 \pm 2.7^{\mathrm{a}}$ & $66.7 \pm 0.2^{a}$ & $22.1 \pm 1.7^{\mathrm{b}}$ & $15.7 \pm 0.8^{b}$ & \\
\hline Org SGR & $32.7 \pm 1.5^{\mathrm{a}}$ & $23.3 \pm 4.4^{\mathrm{a}}$ & $47.2 \pm 0.6^{\mathrm{a}}$ & $61.4 \pm 5.0^{\mathrm{a}}$ & $20.1 \pm 1.5^{b}$ & $15.3 \pm 0.7^{b}$ & \\
\hline Org PBF + P & $24.0 \pm 4.4^{\mathrm{a}}$ & $17.4 \pm 1.2^{\mathrm{ab}}$ & $47.0 \pm 3.7^{\mathrm{a}}$ & $67.2 \pm 0.9^{a}$ & $29.0 \pm 5.97 \mathrm{ab}$ & $15.4 \pm 1.5^{b}$ & \\
\hline Org PBF & $10.1 \pm 2.1^{b}$ & $11.0 \pm 1.1^{\mathrm{b}}$ & $52.4 \pm 1.1^{a}$ & $67.1 \pm 0.5^{\mathrm{a}}$ & $37.5 \pm 2.5^{\mathrm{a}}$ & $21.9 \pm 1.5^{\mathrm{a}}$ & \\
\hline Time & 20.54 & $\begin{array}{c}p \\
0.00 *\end{array}$ & $\begin{array}{l}\mathrm{F} \\
150.74\end{array}$ & $\begin{array}{c}p \\
0.00 *\end{array}$ & $\frac{F}{38.33}$ & $\begin{array}{c}p \\
0.00 *\end{array}$ & \\
\hline Management & 15.57 & 0.00 * & 2.49 & 0.07 & 10.09 & 0.00 * & \\
\hline Time * Management & 2.25 & 0.097 & 0.82 & 0.53 & 2.16 & 0.11 & \\
\hline D Humic Carbon & March 2008 & July 2008 & November 2008 & March 2009 & July 2009 & November 2009 & M Average \\
\hline Management & & & & $\mathrm{g} \mathrm{kg}^{-1}$ & & & \\
\hline Conv WR & $1.1 \pm 0.3$ & $1.2 \pm 0.2$ & $1.8 \pm 0.2$ & $1.2 \pm 0.2$ & $1.2 \pm 0.3$ & $1.2 \pm 0.3$ & $1.2 \pm 0.1^{b}$ \\
\hline Org SGR + C & $4.1 \pm 0.4$ & $5.1 \pm 0.4$ & $5.2 \pm 0.3$ & $3.7 \pm 0.2$ & $2.9 \pm 0.2$ & $3.3 \pm 1.0$ & $4.1 \pm 0.4^{a}$ \\
\hline Org SGR & $3.4 \pm 0.7$ & $4.8 \pm 0.6$ & $4.3 \pm 0.7$ & $4.0 \pm 0.7$ & $3.1 \pm 0.3$ & $2.9 \pm 0.8$ & $3.7 \pm 0.3^{a}$ \\
\hline Org PBF + P & $4.4 \pm 0.6$ & $5.0 \pm 0.5$ & $4.7 \pm 0.2$ & $4.2 \pm 0.0$ & $3.4 \pm 0.4$ & $2.6 \pm 0.3$ & $4.0 \pm 0.0^{a}$ \\
\hline Org PBF & $3.7 \pm 0.7$ & $4.2 \pm 0.3$ & $5.0 \pm 0.3$ & $3.2 \pm 0.2$ & $3.0 \pm 0.5$ & $2.7 \pm 0.7$ & $3.6 \pm 0.3^{a}$ \\
\hline T Average & $3.2 \pm 0.4^{a b}$ & $3.9 \pm 0.4^{a}$ & $4.0 \pm 0.4^{a}$ & $3.1 \pm 0.3^{a b}$ & $2.6 \pm 0.3^{b}$ & $2.4 \pm 0.3^{b}$ & \\
\hline Time & 19.60 & $0.00 *$ & & & & & \\
\hline Management & 15.47 & 0.00 * & & & & & \\
\hline Time * Management & 1.55 & 0.10 & & & & & \\
\hline
\end{tabular}

5A Wet aggregate stability indexes (WASI), pretreated with ethanol (ASA) or benzene pretreatment (BSA). 5B Soil Organic Carbon contents in $\mathrm{mg} \mathrm{kg}^{-1}$. 5C Size Exclusion Chromatografy Humic Fractions in \%. 5D Soil Humic Carbon Content in $\mathrm{mg} \mathrm{kg}^{-1}$. Values are reported with their standard errors. ${ }^{a-b}$ different letters mean significant differences among managements within the same year. M average column compares statistically average values among the theses; $\mathrm{T}$ average row compares statistically average values among all sampling times. ${ }^{*} p<0.05$ values indicate significant differences.

WASI indexes were generally significantly lower in Conv WR than Org managements, especially after ASA, resulting over the years consistently $<30 \%$ compared to values $>45 \%$ in other treatments. 


\subsection{Soil Organic Carbon and Humic Fraction Content}

Soil organic carbon content (Table 5B) was $9.5 \mathrm{~g} \mathrm{~kg}^{-1}$ in March 2008, on average, afterwards it decreased to $8.5 \mathrm{~g} \mathrm{~kg}^{-1}$ (July 2008) which was roughly maintained until the end of the experiment (November 2009). The only significant difference was observed between Conv and Org treatments, the former showing lower values $\left(5.2 \pm 0.4 \mathrm{~g} \mathrm{~kg}^{-1}\right)$ than Org managements $\left(10 \pm 0.2 \mathrm{~g} \mathrm{~kg}^{-1}\right)$ across the years.

Humic matters were characterized by a decrease of high (F1) and low (F3) apparent molecular weight fractions and an increase of intermediate ones (F2), regardless the agricultural system management (Table 5C). Time seems to be the most important factor in humic matter evolution $(p<0.01)$ with no interaction with management. Differences among treatments were statistically significant only for F1 and F3, particularly emphasized by a lower F1, and higher F3, in Org PBF than other organic or conventional treatments.

While the humic matter evolution process was affected by agricultural management systems, the humic carbon content (Table 5D) did not differ significantly across the tested dates. It showed a common pattern among all the organic treatments, with slight increases of humic carbon (HC) content in July and November 2008 and a following decrease, while in Conv WR content did not show significant variations.

\subsection{Interaction between Soil Organic Matter and Soil Stability}

Soil organic carbon and HC showed significant positive correlations with all aggregate stability indexes. Ethanol-pretreated aggregates (ASA) were the most correlated with SOC $(r=0.80)$ and HC $(r=0.73)$, followed by BSA $(r=0.63$ for both SOC and HC) and WSA $(r=0.59$ for both SOC and $\mathrm{HC})$, confirming the role of organic matter in giving stability to soil aggregates (Table 5A). The high molecular weight humic fraction (F1) was the most positively correlated with aggregate stability indexes, in particular with BSA $(r=0.70)$ and ASA $(r=0.73)$ that emphasized the humic matter hydrophobicity and ability to enhance chemical bonds with soil mineral particles (Table 5B).

\subsection{Enzymatic Activity}

Average values of conventional management were always significantly lower than those of organic managements (M average). Among organic managements, dehydrogenase, phosphodiesterase, protease, and urease activities were similar (Tables 6-9, respectively) while phosphomonoesterase, FDA, and $\beta$-glucosidase (Tables 10-12, respectively) activities were higher in thesis with legumes employed as cover/intercrops.

Among the seasons and years (T average), FDA and dehydrogenase showed highest values in summer of both years while $\beta$-glucosidase showed a regular increase from 2008 to 2009 with a peak in July 2009; the two phosphoesterases presented a peak in summer with an irregular trend across the years; protease and urease were constant with a peak in July 2008.

Within the seasons, except for FDA and $\beta$-glucosidase that presented significant differences between March 2008 and March 2009 for Org SGR and Org SGR + C, respectively (Tables 11 and 12), all treatments showed significant differences only between July 2008 and 2009, and/or between November 2008 and 2009. Dehydrogenase activity remained stable in all the situations with the unique difference between $\mathrm{CF}$ and $\mathrm{OF}$. 
Table 6. Dehydrogenase enzymatic activity in soil.

\begin{tabular}{|c|c|c|c|c|c|c|c|}
\hline Dehydrogenase & March 2008 & March 2009 & July 2008 & July 2009 & November 2008 & November 2009 & M Average \\
\hline Management & \multicolumn{7}{|c|}{ g INTF $^{-1}$ dry soil $^{-1}$} \\
\hline Conv WR & (R) - & (WR) $0.04 \pm 0.00$ & $(-) 0.04 \pm 0.00$ & (W) $0.03 \pm 0.00$ & (WR) $0.02 \pm 0.00$ & (W) $0.05 \pm 0.01$ & $0.04 \pm 0.00^{b}$ \\
\hline Org SGR + C & (C) - & (CG) $0.11 \pm 0.02$ & (CS) $0.20 \pm 0.03$ & (CG) $0.23 \pm 0.04$ & (CG) $0.12 \pm 0.02$ & (R) $0.09 \pm 0.01$ & $0.15 \pm 0.025^{a}$ \\
\hline Org SGR & $(-)-$ & (G) $0.13 \pm 0.02$ & (S) $0.14 \pm 0.02$ & (G) $0.12 \pm 0.01$ & (G) $0.09 \pm 0.02$ & (R) $0.07 \pm 0.02$ & $0.11 \pm 0.01^{a}$ \\
\hline Org PBF + P & (C) - & (BP) $0.13 \pm 0.01$ & $(\mathrm{Pu}) 0.14 \pm 0.02$ & (F) $0.17 \pm 0.01$ & (BP) $0.10 \pm 0.02$ & (-) $0.10 \pm 0.02$ & $0.13 \pm 0.01^{a}$ \\
\hline Org PBF & $(-)-$ & (B) $0.11 \pm 0.02$ & $(\mathrm{Pu}) 0.10 \pm 0.03$ & (F) $0.13 \pm 0.05$ & (B) $0.10 \pm 0.01$ & $(-) 0.07 \pm 0.01$ & $0.10 \pm 0.01^{a}$ \\
\hline T Average & $\overline{\mathrm{F}}$ & $0.10 \pm \underset{p}{0.01} 1^{a b c}$ & $0.12 \pm 0.02^{a b}$ & $0.13 \pm 0.02^{a}$ & $0.08 \pm 0.01^{b c}$ & $0.08 \pm 0.01^{c}$ & \\
\hline $\begin{array}{c}\text { Time } \\
\text { Management }\end{array}$ & $\begin{array}{l}12.1 \\
9.24\end{array}$ & $\begin{array}{l}0.005 \text { * } \\
0.002\end{array}$ * & & & & & \\
\hline $\begin{array}{l}\text { Time } \\
\text { Management }\end{array}$ & 4.056 & 0.029 * & & & & & \\
\hline
\end{tabular}

Dehydrogenase activity is expressed in $\mathrm{g}$ of INTF $\mathrm{g}^{-1}$ dry soil $\mathrm{h}^{-1}$ formed by reduction of INT. Each row indicates the evolution of dehydrogenase activity during the experimental period in each thesis. M average column compares statistically average values among the theses; T average row compares statistically average values among all sampling times; ${ }^{\mathrm{a}-\mathrm{c}}$ letters indicate significant differences among the values. Each row compares same months of different years: values in bold mean significant differences between 2008 and 2009 by paired $T$ test. Capital letters in parenthesis indicate the crops. No letter means bared soil. - = missing data; $\mathrm{B}=\mathrm{barley} ; \mathrm{C}=\mathrm{clover} ; \mathrm{F}=$ fennel; $\mathrm{G}=$ garlic; $\mathrm{P}=$ pea; $\mathrm{Pu}=$ pumpkin; $\mathrm{R}=$ rapeseed $/$ radicchio; $\mathrm{S}=$ sorgum; $\mathrm{W}=$ wheat. ${ }^{*} p<0.05$ values indicate significant differences.

Table 7. Phosphodiesterase enzymatic activity in soil.

\begin{tabular}{|c|c|c|c|c|c|c|c|}
\hline Phosphodiesterase & March 2008 & March 2009 & July 2008 & July 2009 & November 2008 & November 2009 & M Average \\
\hline Management & \multicolumn{7}{|c|}{$\mathrm{g}$ of bis- $p$-nitrophenol $\mathrm{g}^{-1}$ of dry soil $\mathrm{h}^{-1}$} \\
\hline Conv WR & $\begin{array}{c}\text { (R) } \\
22.09 \pm 1.69\end{array}$ & $\begin{array}{c}\text { (WR) } \\
25.24 \pm 2.67\end{array}$ & $20.13^{(-)} \pm 1.66$ & $\begin{array}{c}(W) \\
24.96 \pm 5.36\end{array}$ & $\begin{array}{c}\text { (WR) } \\
16.86 \pm 2.09\end{array}$ & $\begin{array}{c}(W) \\
15.68 \pm 2.25\end{array}$ & $20.83 \pm 1.64^{b}$ \\
\hline Org SGR + C & $\begin{array}{c}(\mathrm{C}) \\
70.72 \pm 5.37\end{array}$ & $\begin{array}{c}\text { (CG) } 77.25 \pm \\
10.66\end{array}$ & $\begin{array}{c}\text { (CS) } \\
61.37 \pm 3.93\end{array}$ & $\begin{array}{c}\text { (CG) } \\
106.12 \pm 6.71 \\
\end{array}$ & $\begin{array}{c}\text { (CG) } \\
62.78 \pm 5.14\end{array}$ & $\begin{array}{c}\text { (R) } \\
40.09 \pm 3.67\end{array}$ & $61.33 \pm 8.90^{a}$ \\
\hline Org SGR & $\begin{array}{c}(-) \\
61.62 \stackrel{1}{ \pm} 14.15\end{array}$ & $\begin{array}{c}(\mathrm{G}) \\
71.90 \pm 9.37\end{array}$ & $\begin{array}{c}\text { (S) } \\
52.78 \pm 8.28\end{array}$ & $\begin{array}{c}\text { (G) } \\
92.98 \pm 15.03\end{array}$ & $\begin{array}{c}(\mathrm{G}) \\
61.68 \pm 14.76\end{array}$ & $\begin{array}{c}(\mathrm{R}) \\
33.00 \pm 2.15\end{array}$ & $62.33 \pm 8.13^{a}$ \\
\hline Org PBF + P & $\begin{array}{c}(\mathrm{C}) \\
61.78 \pm 2.73\end{array}$ & $\begin{array}{c}\text { (BP) } 91.86 \pm \\
14.08\end{array}$ & $\begin{array}{c}(\mathrm{Pu}) \\
60.74 \pm 5.83\end{array}$ & $\begin{array}{c}\text { (F) } \\
92.42 \pm 5.50\end{array}$ & $\begin{array}{c}\text { (BP) } 68.19 \pm \\
10.60\end{array}$ & $\begin{array}{c}(-) \\
42.36^{(-)} \pm 1.17\end{array}$ & $69.56 \pm 7.96^{a}$ \\
\hline Org PBF & $66.91 \stackrel{(-)}{ \pm} 12.03$ & $\begin{array}{c}\text { (B) } \\
79.64 \pm 8.56\end{array}$ & $\begin{array}{c}(\mathrm{Pu}) \\
44.16 \pm 1.31\end{array}$ & $\begin{array}{c}\text { (F) } \\
82.39 \stackrel{\text { 土 }}{ \pm} .69\end{array}$ & $\begin{array}{c}\text { (B) } \\
59.30 \pm 10.33\end{array}$ & $35.59^{(-)} \pm 2.46$ & $69.72 \pm 7.68^{a}$ \\
\hline $\begin{array}{c}\text { 6T Average } \\
\text { Time } \\
\text { Management } \\
\text { Time * } \\
\text { Management }\end{array}$ & $\begin{array}{c}54.47 \pm 5.80^{b c} \\
\mathrm{~F} \\
42.65 \\
17.30 \\
2.71\end{array}$ & $\begin{array}{c}66.43 \pm 7.25^{a b} \\
p \\
0.00^{*} \\
0.00^{*} \\
0.002^{*}\end{array}$ & $46.11 \pm 4.54^{c d}$ & $76.35 \pm 8.47^{a}$ & $51.45 \pm 6.24^{b c}$ & $32.24 \pm 2.77^{d}$ & \\
\hline
\end{tabular}

Phosphodiesterase activity is expressed in $\mathrm{g}$ of $\mathrm{p}$-nitrophenol $\mathrm{g}^{-1} \mathrm{dry} \mathrm{soil} \mathrm{h}^{-1}$. Each row indicates the evolution of phosphodiesterase activity during the experimental period in each thesis. M average column compares statistically average values among the theses; $\mathrm{T}$ average row compares statistically average values among all sampling times; ${ }^{\text {a-d }}$ letters indicate significant differences among the values. Each row compares same months of different years: values in bold mean significant differences between 2008 and 2009 by paired $T$ test. Capital letters in parenthesis indicate the crops. No letter means bared soil. $\mathrm{B}=$ barley; $\mathrm{C}=$ clover; $\mathrm{F}=$ fennel; $\mathrm{G}=$ garlic; $\mathrm{P}=$ pea; $\mathrm{Pu}=$ pumpkin; $\mathrm{R}=$ rapeseed $/$ radicchio; $\mathrm{S}=$ sorghum; $\mathrm{W}=$ wheat. ${ }^{*} p<0.05$ values indicate significant differences. 
Table 8. Protease enzymatic activity in soil.

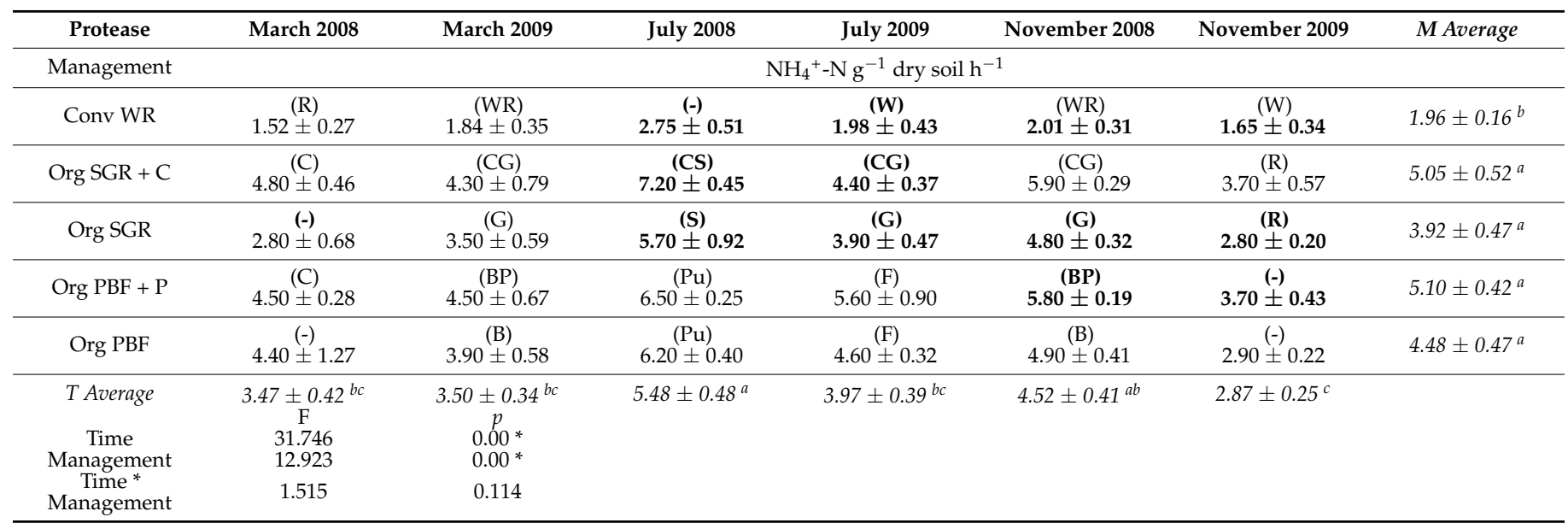

Protease activity is expressed protease activities were determined as $\mu \mathrm{g} \mathrm{NH}^{4+} \mathrm{g}^{-1}$ dry soil $\mathrm{h}^{-1}$ released in the hydrolysis reaction. Each row indicates the evolution of protease activity during the experimental period in each thesis. M average column compares statistically average values among the theses; $T$ average row compares statistically average values among all sampling times; ${ }^{\mathrm{a}-\mathrm{c}}$ letters indicate significant differences among the values. Each row compares same months of different years: values in bold mean significant differences between 2008 and 2009 by paired $T$ test. Capital letters in parenthesis indicate the crops. No letter means bared soil. $B=$ barley; $C=$ clover; $F=$ fennel; $G=$ garlic; $\mathrm{P}=$ pea; $\mathrm{Pu}=$ pumpkin; $\mathrm{R}=$ rapeseed $/$ radicchio; $\mathrm{S}=$ sorghum; $\mathrm{W}=$ wheat. ${ }^{*} p<0.05$ values indicate significant differences.

Table 9. Urease enzymatic activity in soil.

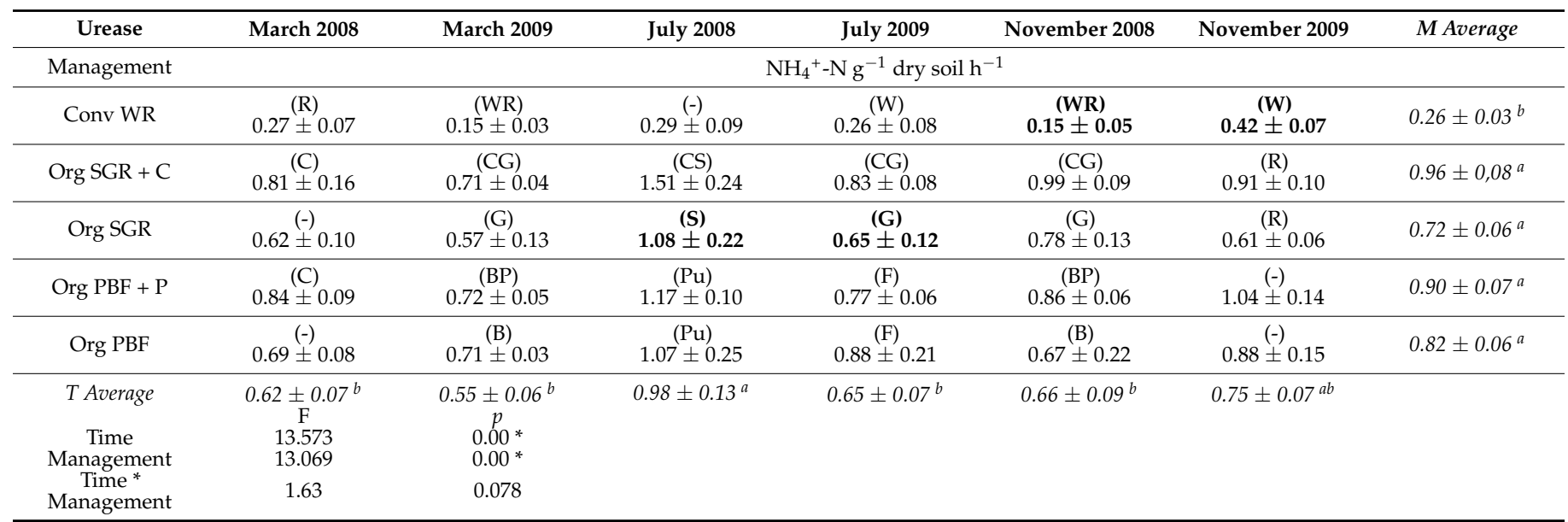

Urease activity is expressed protease activities were determined as $\mu \mathrm{g} \mathrm{NH} 4^{+} \mathrm{g}^{-1}$ dry soil $\mathrm{h}^{-1}$ released in the hydrolysis reaction. Each row indicates the evolution of Urease activity during the experimental period in each thesis. M average column compares statistically average values among the theses; $\mathrm{T}$ average row compares statistically average values among all sampling times; ${ }^{a-b}$ letters indicate significant differences among the values. Each row compares same months of different years: values in bold mean significant differences between 2008 and 2009 by paired $T$ test. Capital letters in parenthesis indicate the crops. No letter means bared soil. B = barley; $\mathrm{C}=\mathrm{clover} ; \mathrm{F}=\mathrm{fennel} ; \mathrm{G}=$ garlic; $\mathrm{P}=$ pea; $\mathrm{Pu}=$ pumpkin; $\mathrm{R}=$ rapeseed / radicchio; $\mathrm{S}=$ sorghum; $\mathrm{W}=$ wheat. ${ }^{*} p<0.05$ values indicate significant differences. 
Table 10. Phosphomonoesterase enzymatic activity in soil.

\begin{tabular}{|c|c|c|c|c|c|c|c|}
\hline \multicolumn{2}{|c|}{ PhosphomonoesteraseMarch 2008} & March 2009 & July 2008 & July 2009 & November 2008 & November 2009 & M Average \\
\hline Management & \multicolumn{7}{|c|}{ g of bis-p-nitrophenol g of dry soil ${ }^{-1} \mathrm{~h}^{-1}$} \\
\hline Conv WR & $\begin{array}{c}\text { (R) } \\
129.99 \pm 64.99\end{array}$ & $\begin{array}{c}\text { (WR) } \\
125.67 \pm 19.68\end{array}$ & $137.73 \stackrel{(-)}{ \pm} 14.25$ & $\begin{array}{c}(W) \\
118.47 \pm 10.85\end{array}$ & $\begin{array}{c}\text { (WR) } \\
94.50 \pm 10.79\end{array}$ & $\begin{array}{c}(W) \\
159.93 \pm 23.45\end{array}$ & $127.71 \pm 12.01^{c}$ \\
\hline Org SGR + C & $\begin{array}{c}(\mathrm{C}) \\
360.29 \pm 40.09\end{array}$ & $\begin{array}{c}\text { (CG) } 301.94 \pm \\
7.00\end{array}$ & $\begin{array}{c}\text { (CS) } \\
458.72 \pm 19.99 \\
\end{array}$ & $\begin{array}{c}\text { (CG) } \\
250.89 \pm 7.85\end{array}$ & $\begin{array}{c}\text { (CG) } \\
319.10 \pm 4.62\end{array}$ & $\begin{array}{c}\text { (R) } \\
289.83 \pm 4.03\end{array}$ & $330.13 \pm 13.87^{a}$ \\
\hline Org SGR & $\begin{array}{l}\text { (-) } 276.83 \pm \\
21.86\end{array}$ & $\begin{array}{c}(\mathrm{G}) \\
268.76 \pm 15.42\end{array}$ & $\begin{array}{c}(\mathrm{S}) \\
345.20 \pm 39.69\end{array}$ & $\begin{array}{c}(\mathrm{G}) \\
251.82 \pm 10.39\end{array}$ & $\begin{array}{c}\text { (G) } \\
250.82 \pm 8.18\end{array}$ & $\begin{array}{c}\text { (R) } \\
291.14 \pm 2.82\end{array}$ & $280.76 \pm 13.87^{b}$ \\
\hline Org PBF + P & $\begin{array}{c}(\mathrm{C}) \\
308.57 \pm 35.89\end{array}$ & $\begin{array}{c}\text { (BP) } 294.39 \pm \\
14.70\end{array}$ & $\begin{array}{c}\text { (Pu) } 409.98 \pm \\
13.29\end{array}$ & $\begin{array}{c}\text { (F) } \\
247.12 \pm 5.68\end{array}$ & $\begin{array}{c}\text { (BP) } 293.00 \pm \\
11.71\end{array}$ & $280.81^{(-)} \pm 5.61$ & $305.65 \pm 13.87^{a b}$ \\
\hline Org PBF & $287.94^{(-)} \pm 19.54$ & $\begin{array}{c}\text { (B) } \\
298.20 \pm 14.48\end{array}$ & $\begin{array}{c}(\mathrm{Pu}) 343.14 \pm \\
34.38\end{array}$ & $\begin{array}{c}(\mathrm{F}) \\
249.26 \pm 4.48\end{array}$ & $\begin{array}{c}\text { (B) } \\
256.86 \pm 23.28\end{array}$ & $282.64^{(-)} \pm 2.53$ & $286.34 \pm 13.87^{a b}$ \\
\hline T Average & $263.80 \underset{\mathrm{F}}{ \pm} 23.41^{b}$ & $249.54 \underset{p}{ \pm} 19.66^{b}$ & $326.38 \pm 31.64^{a}$ & $216.95 \pm 15.07^{b}$ & $233.59 \pm 22.21^{b}$ & $254.56 \pm 15.13^{b}$ & \\
\hline $\begin{array}{c}\text { Time } \\
\text { Management }\end{array}$ & $\begin{array}{l}25.885 \\
40.825\end{array}$ & $\begin{array}{l}0.00 \text { * } \\
0.00 \text { * }\end{array}$ & & & & & \\
\hline $\begin{array}{c}\text { Time * } \\
\text { Management }\end{array}$ & 6.606 & $0.006 *$ & & & & & \\
\hline
\end{tabular}

Phosphomonoesterase activity is expressed in $\mathrm{g}$ of $\mathrm{p}$-nitrophenol $\mathrm{g}^{-1} \mathrm{dry}$ soil $\mathrm{h}^{-1}$. Each row indicates the evolution of phosphomonoesterase activity during the experimental period in each thesis. M average column compares statistically average values among the theses; $\mathrm{T}$ average row compares statistically average values among all sampling times; ${ }^{\mathrm{a}-\mathrm{c}}$ letters indicate significant differences among the values. Each row compares same months of different years: values in bold mean significant differences between 2008 and 2009 by paired $T$ test. Capital letters in parenthesis indicate the crops. No letter means bared soil. $\mathrm{B}=$ barley; $\mathrm{C}=$ clover; $\mathrm{F}=$ fennel; $\mathrm{G}=$ garlic; $\mathrm{P}=$ pea; $\mathrm{Pu}=$ pumpkin; $\mathrm{R}=$ rapeseed $/$ radicchio; $\mathrm{S}=$ sorghum; $\mathrm{W}=$ wheat. ${ }^{*} p<0.05$ values indicate significant differences.

Table 11. Total microbial enzymatic activity measured by fluorescein diacetate hydrolase (FDA) activity in soil.

\begin{tabular}{|c|c|c|c|c|c|c|c|}
\hline FDA & March 2008 & March 2009 & July 2008 & July 2009 & November 2008 & November 2009 & M Average \\
\hline Management & \multicolumn{7}{|c|}{$\mathrm{g}_{\text {fluorescein }} \mathrm{g}^{-1}$ dry soil $\mathrm{h}^{-1}$} \\
\hline Conv WR & $\begin{array}{c}(\mathrm{R}) \\
0.10 \stackrel{ \pm}{ \pm} 0.02\end{array}$ & $\begin{array}{c}\text { (WR) } \\
0.32 \pm 0.08\end{array}$ & $\begin{array}{c}(-) \\
0.31 \stackrel{(1}{ \pm} 0.02\end{array}$ & $\begin{array}{c}(\mathrm{W}) \\
0.31 \pm 0.04\end{array}$ & $\begin{array}{c}\text { (WR) } \\
0.09 \pm 0.03\end{array}$ & $\begin{array}{c}(W) \\
0.41 \pm 0.11\end{array}$ & $0.26 \pm 0.05^{d}$ \\
\hline Org SGR + C & $\begin{array}{c}(\mathrm{C}) \\
0.66 \pm 0.11\end{array}$ & $\begin{array}{c}\text { (CG) } \\
0.95 \pm 0.11\end{array}$ & $\begin{array}{c}(\mathrm{CS}) \\
1.61 \pm 0.19\end{array}$ & $\begin{array}{c}\text { (CG) } \\
1.46 \pm 0.10\end{array}$ & $\begin{array}{c}\text { (CG) } \\
1.00 \pm 0.13\end{array}$ & $\begin{array}{c}(\mathrm{R}) \\
1.50 \stackrel{ \pm}{ \pm} 0.20\end{array}$ & $1.20 \pm 0.15^{a b}$ \\
\hline Org SGR & $\begin{array}{c}(-) \\
0.38 \stackrel{+}{ \pm} 0.04\end{array}$ & $\begin{array}{c}\text { (G) } \\
1.00 \pm 0.17\end{array}$ & $\begin{array}{c}(\mathrm{S}) \\
1.16 \stackrel{ \pm}{ \pm} 0.27\end{array}$ & $\begin{array}{c}(\mathrm{G}) \\
1.24 \pm 0.23\end{array}$ & $\begin{array}{c}(\mathrm{G}) \\
0.66 \pm 0.16\end{array}$ & $\begin{array}{c}\text { (R) } \\
0.90 \pm 0.14\end{array}$ & $0.89 \pm 0.13^{c}$ \\
\hline Org PBF + P & $\begin{array}{c}(\mathrm{C}) \\
0.59 \pm 0.02\end{array}$ & $\begin{array}{c}\text { (BP) } \\
1.27 \pm 0.29\end{array}$ & $\begin{array}{c}(\mathrm{Pu}) \\
1.49 \pm 0.02\end{array}$ & $\begin{array}{c}(\mathrm{F}) \\
1.56 \stackrel{ }{ \pm} 0.14\end{array}$ & $\begin{array}{c}\text { (BP) } \\
1.04 \pm 0.12\end{array}$ & $1.56 \stackrel{(-)}{ \pm} 0.04$ & $1.25 \pm 0.16^{a}$ \\
\hline Org PBF & $\begin{array}{c}(-) \\
0.67 \stackrel{(1)}{ \pm} 0.26\end{array}$ & $\begin{array}{c}\text { (B) } \\
1.01 \stackrel{ \pm}{ \pm} 0.18\end{array}$ & $\begin{array}{c}(\mathrm{Pu}) \\
1.12 \pm 0.16\end{array}$ & $\begin{array}{c}(\mathrm{F}) \\
1.10 \stackrel{ \pm}{ \pm} 0.21\end{array}$ & $\begin{array}{c}\text { (B) } \\
0.69 \stackrel{ \pm}{ \pm} 0.14\end{array}$ & $0.93 \stackrel{(-)}{ \pm} 0.13$ & $0.92 \pm 0.08^{b c}$ \\
\hline $\begin{array}{c}\text { T Average } \\
\text { Time } \\
\text { Management } \\
\text { Time* } \\
\text { Management }\end{array}$ & $\begin{array}{c}0.45 \pm 0.07^{c} \\
F \\
24.256 \\
22.393 \\
1.662\end{array}$ & $\begin{array}{c}0.87 \pm 0.11^{a b} \\
p \\
0.00^{*} \\
0.00^{*} \\
0.07\end{array}$ & $1.09 \pm 0.14^{a}$ & $1.08 \pm 0.13^{a}$ & $0.66 \pm 0.10^{b c}$ & $1.02 \pm 0.12^{a}$ & \\
\hline
\end{tabular}

FDA diacetate hydrolase activity is expressed in $\mathrm{mg}$ of fluorescein released $\mathrm{g}^{-1}$ dry soil $\mathrm{h}^{-1}$. Each row indicates the evolution of FDA activity during the experimental period in each thesis. M average column compares statistically average values among the theses; $\mathrm{T}$ average row compares statistically average values among all sampling times; ${ }^{\text {a-d }}$ letters indicate significant differences among the values. Each row compares same months of different years: values in bold mean significant differences between 2008 and 2009 by paired $T$ test. Capital letters in parenthesis indicate the crops. No letter means bared soil. $\mathrm{B}=$ barley; $\mathrm{C}=$ clover; $\mathrm{F}=$ fennel; $\mathrm{G}=$ garlic; $\mathrm{P}=$ pea; $\mathrm{Pu}=$ pumpkin; $\mathrm{R}=$ rapeseed/radicchio; $\mathrm{S}=$ sorghum; $\mathrm{W}=$ wheat. ${ }^{*} p<0.05$ values indicate significant differences. 
Table 12. $\beta$-Glucosidase enzymatic activity in soil.

\begin{tabular}{|c|c|c|c|c|c|c|c|}
\hline$\beta$-Glucosidase & March 2008 & March 2009 & July 2008 & July 2009 & November 2008 & November 2009 & M Average \\
\hline Management & \multicolumn{7}{|c|}{ g p-nitrophenol g ${ }^{-1}$ dry soil $^{-1}$} \\
\hline Conv WR & $\begin{array}{c}\text { (R) } \\
16.13 \pm 3.58\end{array}$ & $\begin{array}{c}\text { (WR) } \\
15.75 \pm 2.83\end{array}$ & $17.35^{(-)} \pm 2.84$ & $\begin{array}{c}(W) \\
18.29 \pm 1.28\end{array}$ & $\begin{array}{c}\text { (WR) } \\
8.61 \pm 1.10\end{array}$ & $\begin{array}{c}(W) \\
24.64 \pm 4.47\end{array}$ & $16.80 \pm 2.10^{c}$ \\
\hline Org SGR + C & $\begin{array}{c}(C) \\
64.79 \pm 2.89\end{array}$ & $\begin{array}{c}\text { (CG) } \\
105.63 \pm 8.57\end{array}$ & $\begin{array}{c}\text { (CS) } 114.17 \pm \\
17.40\end{array}$ & $\begin{array}{c}\text { (CG) } 154.60 \pm \\
6.59\end{array}$ & $\begin{array}{c}\text { (CG) } \\
73.54 \pm 6.21\end{array}$ & $\begin{array}{c}\text { (R) } \\
103.52 \pm 18.77\end{array}$ & $102.70 \pm 13.07^{a}$ \\
\hline Org SGR & (-) $55.96 \pm 10.66$ & $\begin{array}{c}(\mathrm{G}) \\
56.80 \pm 8.90\end{array}$ & $\begin{array}{c}(\mathrm{S}) \\
53.96 \pm 7.81\end{array}$ & $\begin{array}{c}(\mathrm{G}) \\
67.33 \pm 14.87\end{array}$ & $\begin{array}{c}\text { (G) } \\
38.78 \pm 5.99\end{array}$ & $\begin{array}{c}\text { (R) } \\
58.68 \pm 4.57\end{array}$ & $55.25 \pm 3.80^{b}$ \\
\hline Org PBF + P & $\begin{array}{c}(\mathrm{C}) \\
80.04 \pm 18.59\end{array}$ & $\begin{array}{c}\text { (BP) } \\
80.73 \pm 7.05\end{array}$ & $\begin{array}{c}(\mathrm{Pu}) 108.29 \pm \\
12.00\end{array}$ & $\begin{array}{c}(\mathrm{F}) \\
115.45 \pm 11.02\end{array}$ & $\begin{array}{c}(\mathrm{BP}) \\
82.97 \pm 12.87\end{array}$ & $\begin{array}{c}(-) \\
104.08 \pm 7.26\end{array}$ & $95.26 \pm 6.45^{a}$ \\
\hline Org PBF & (-) $58.43 \pm 11.59$ & $\begin{array}{c}\text { (B) } \\
55.86 \pm 6.38\end{array}$ & $\begin{array}{c}(\mathrm{Pu}) \\
60.32 \pm 7.13\end{array}$ & $99.13 \stackrel{(F)}{ \pm 26.06}$ & $\begin{array}{c}\text { (B) } \\
46.54 \pm 3.64\end{array}$ & 67.51 $\stackrel{(-)}{ \pm} 7.16$ & $64.63 \pm 7.44^{b}$ \\
\hline $\begin{array}{c}\text { T Average } \\
\text { Time } \\
\text { Management } \\
\text { Time* } \\
\text { Management }\end{array}$ & $\begin{array}{c}52.64 \pm 7.05^{b} \\
\mathrm{~F} \\
15.116 \\
35.554 \\
2.415\end{array}$ & $\begin{array}{c}60.00 \pm 8.42^{a b} \\
p \\
0.00^{*} \\
0.00^{*} \\
0.005^{*}\end{array}$ & $67.48 \pm 10.36^{a b}$ & $86.42 \pm 13.39^{a}$ & $47.49 \pm 7.53^{b}$ & $68.75 \pm 8.79^{a b}$ & \\
\hline
\end{tabular}

$\beta$-Glucosidase activity is expressed in $\mathrm{g}$ of $\mathrm{p}$-nitrophenol $\mathrm{g}^{-1}$ dry soil $\mathrm{h}^{-1}$. Each row indicates the evolution of $\beta$-glucosidase activity during the experimental period in each thesis. $\mathrm{M}$ average column compares statistically average values among the theses; $\mathrm{T}$ average row compares statistically average values among all sampling times; ${ }^{\mathrm{a}-\mathrm{b}}$ italic letters indicate significant differences among the values. Each row compares same months of different years: values in bold mean significant differences between 2008 and 2009 by paired $T$ test. Capital letters in parenthesis indicate the crops. No letter means bared soil. $\mathrm{B}=$ barley; $\mathrm{C}=$ clover; $\mathrm{F}=$ fennel; $\mathrm{G}=$ garlic; $\mathrm{P}=$ pea; $\mathrm{Pu}=$ pumpkin; $\mathrm{R}=$ rapeseed $/$ radicchio; $\mathrm{S}=$ sorghum; $\mathrm{W}=$ wheat. ${ }^{*} p<0.05$ values indicate significant differences.

\subsection{Canonical Discriminant Analysis}

CDA analysis was performed (1) to confirm the differences in soil fertility parameters between CF and OF systems and (2) to evaluate the effects of diverse crop rotations on soil biochemical properties.

The scatter plot (Figure 1) of the first two extracted canonical roots showed that CAN 1 (accounting for $80.09 \%$ of the model variability) well discriminated Conv WR and Org SGR from Org PBF + P and Org PBF, whereas CAN 2 (explaining 17.48\%) discriminated Org SGR from the other managements. The canonical scores are reported in supplementary data. The overall Wilk's Lambda was $0.0074(\mathrm{~F}=10.01 ; p<0.0001)$. The Mahalanobis quadratic distances of the 5 clouds and their significance (Tables A1 and A2) are reported in Appendix A. Values indicated that only Org PBF + P and Org PBF were not significantly different.

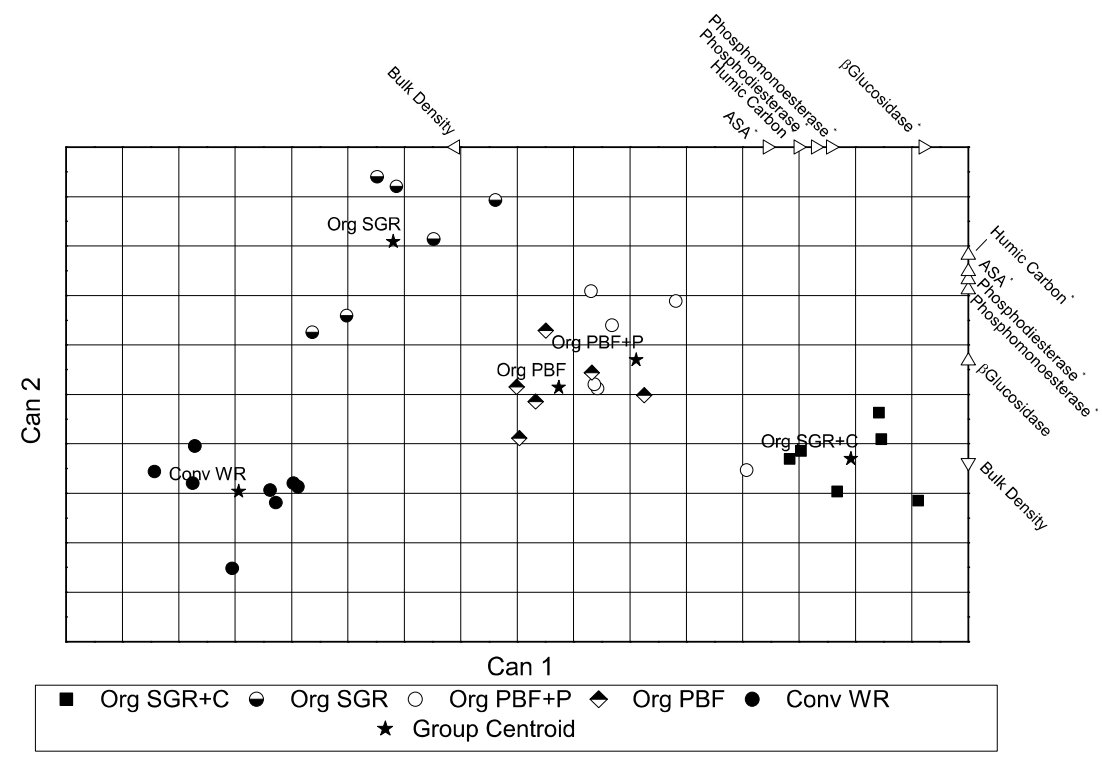

Figure 1. Canonical discriminant analysis scatter plot showing the separation of samples from the different plots. Additional axes show the most important variables contributing to the formation of the canonical variables. The extension of each arrow from the plot center indicates the importance of the variable in the canonical structure according to Pearson correlation coefficients and its direction reports the increase or decrease of the variable. Stars indicate centroid of each cloud. 
Variables that significantly contributed to the CDA model were the enzymatic activities $\beta$-glucosidase, phosphomonoesterase, phosphodiesterase, the humic carbon content, and the soil physical properties of aggregate stability (ASA) and bulk density (Figure 1). These variables were not equally important in the construction of the canonical functions, as demonstrated by Pearson correlation coefficients and significance levels (Table A2). Although, contributing to the model, bulk density values did not correlate with the canonical axes, while all other factors significantly correlate with the two canonical functions.

\section{Discussion}

\subsection{Soil Organic Matter and Stability Indexes}

Since the first sampling to the end of the experiment, Conv WR showed significantly lower topsoil content of both SOC and HC (Table 5B). These results were likely due to the combined effect of different fertilization (mineral in Conv vs. organic in Org) and tillage operations (intensive in Conv vs. minimum in Org), that were primarily involved in SOC change dynamics as also observed in other studies [45]. However, all treatments showed SOC and HC reduction, highlighting the poor ability of coarse texture soils to form stable organo-mineral complexes that would protect the organic matter from mineralization. These results corroborated previous findings in similar pedo-climatic conditions, where different soil improving cropping systems were compared for SOC stock in a 6-year experiment, and results revealed that they suffered from low soil reactivity to SOC accumulation dynamics [46]. These dynamics are in contrast with long-term studies where SOC accumulation dynamics occurred in different soil types, either clayey, loamy, or sandy [47]. In our experiment, the topsoil SOC depletion could be related with: (i) the short time of the experimental monitoring; (ii) the effects of soil disturbance and SOC mineralization with minimum tillage that counteracted the topsoil organic carbon accumulation with no tillage in previous years in the same plots. The latter seems in agreement with previous studies [48,49], where a topsoil SOC content was partially lost just after some greater intensity in soil tillage operations, suggesting that aggregate breakdown stimulation and reduced SOC protection occurred [50].

The results about WASIs corroborated previous findings on the strong relationship between SOC content and structure [51,52]: here, a trend towards a loss of aggregate structure stability was observed from early 2008 to 2009, which was consistent with the SOC and HC depletion. In addition, significant WASIs reductions were observed when more intensive tillage operations-under Conv—were compared with minimum tillageunder Org.

The wet mechanical cohesion between soil and organic matter particles assumed particular importance, being ASA stability indexes always greater in Org compared to Conv. In contrast, the BSA index had little differentiation between treatments, suggesting that the hydrophobic behavior of soil organic matter to protect the structure was likely a secondary mechanism.

Humic matter hydrophobicity may not be the most significant factor in improving aggregates stability [38], this is consistent with our data: although with the clear evolution of humic substances (Table 5B) towards the intermediate molecular fraction, there is no evidence of increased aggregate stability through WASI tests (Table 5A); those, conversely, showed a general decrease of stability in agreement with OC and HC decrease. On the other side, the clear correlation among WASIs indexes (especially ASA) and high molecular weight fraction (Table 13) can suggest that F1 can exert an influence on the chemical bonding that affects aggregates stability. This is corroborated by previous findings [9] that reported strong positive correlations $(\mathrm{r}>0.90)$ between $\mathrm{F} 1$ and carboxyl groups, which in turn are responsible for strong soil-SOM chemisorptive bondings, especially in soils with low SOC content $<1 \%$ [14]. We argue that the decrease of bulk density (Table 4 ), which could be a signal of enhanced porosity, was the consequence of conventional and light ploughing that broke down the superficial layer after the no cultivation period. A slow reaction to improve soil structure properties in similar silty soils with low organic carbon 
content was also observed in previous studies, [53], suggesting that long-term strategies to increase the chemical and physical soil fertility are required.

Table 13. Pearson's correlations.

\begin{tabular}{|c|c|c|c|c|c|c|}
\hline A & WSA & BSA & ASA & Frac 1 & Frac 2 & Frac 3 \\
\hline \multirow{2}{*}{ SOC } & $0.59 * *$ & $0.63 * *$ & $0.80 * *$ & $0.46^{* *}$ & -0.18 & -0.26 \\
\hline & 0.00 & 0.00 & 0.00 & 0.01 & 0.32 & 0.15 \\
\hline \multirow{2}{*}{$\mathrm{HC}$} & 0.59 ** & $0.63 * *$ & 0.73 ** & $0.66^{* *}$ & -0.10 & $-0.56^{* *}$ \\
\hline & 0.00 & 0.00 & 0.00 & 0.00 & 0.59 & 0.00 \\
\hline B & Frac 1 & Frac 2 & Frac 3 & & & \\
\hline \multirow{2}{*}{ WSA } & $0.63^{* *}$ & -0.07 & $-0.55^{* *}$ & & & \\
\hline & 0.00 & 0.69 & 0.00 & & & \\
\hline \multirow{2}{*}{ BSA } & 0.70 ** & $-0.39 *$ & -0.28 & & & \\
\hline & 0.00 & 0.03 & 0.12 & & & \\
\hline \multirow{2}{*}{ ASA } & $0.73 * *$ & -0.43 * & -0.26 & & & \\
\hline & 0.00 & 0.01 & 0.16 & & & \\
\hline
\end{tabular}

(A) Pearson's correlation of soil organic carbon (SOC) and humic carbon (HC) content with water (WSA), benzene (BSA), and ethanol (ASA) stability assays and the 3 humic fractions. (B) Pearson's correlation among soil stability assays and humic fractions. ${ }^{* *}$ means significant at $p<0.01$. ${ }^{*}$ means significant at $p<0.05$. In bold are indicated the strongest positive correlations. Values in italic indicate significativity.

\subsection{Enzymatic Activities}

All enzymes activities considered in this work show higher values in organic treatments than conventional one but with noticeable differences among themselves.

Fluorescein diacetate (FDA) hydrolysis and $\beta$-glucosidase are indicators of total enzymatic activity due to the capability of many enzymes free or bound to cell membranes to hydrolyze fluorescein diacetate, and the presence of $\beta$-glucosidase in circulant solution or in fungi: agricultural practices involving minimum soil disturbance, maximizing soil cover, and the use of organic amendments can contribute to improve $\beta$-glucosidase activity through the increase of fungi presence and organic $C$ but FDA also displayed modifications caused by climate [54-56]. Our data showed a peak of activity for FDA in correspondence with the warmer periods of the experiment (July 2008 and 2009) while $\beta$-glucosidase showed also peak in November 2009. Interestingly, our data do not match with works cited above about direct relationship between $C$ increase and enzymatic activity increase as we recorded a general OC and HC decrease, in particular from March 2008 to July 2008 and a following steady state until the end of the trial. Although in this trend, enzymatic activity of FDA hydrolases and $\beta$-glucosidase increased in all thesis except Conv WR for $\beta$-glucosidase. An explanation could be one as described in Weerasekara [57]: under the legume hairy vetch and cereal rye employed as cover crops in silty loam or sand, $\beta$-glucosidase increased its activity while FDA hydrolases significantly decreased. This is consistent with thesis Org SGR $+C$ that employs a cereal (sorghum) as one of main crops plus a legume as cover and associate crop (clover) in a sandy loam soil: not only average $\beta$-glucosidase values are the highest but it shows the higher increase between the same seasons of the two years (Table 13). Conversely, FDA activity increased and remained higher in thesis Org SGR + C and Org PBF + P characterized by cereals + legumes (Table 11).

Plant diversity can increase microbial activity and carbon storage as result mainly of new carbon integration by microbial community [58] but there seems the need of the "right combination" of crops, soil, management, and climate in order to achieve some specific results in term of biological activity.

In our work, dehydrogenase activity did not show any significant change within each thesis during the experimental period (Table 6) nor among organic managements. In 
the present work, this enzymatic activity seems to depend on the organic carbon content that remained roughly stable in the present experiment, after a first decrease. Previous long-term data confirmed the relation among dehydrogenase activity and OC content [59]. Lange at al. indicated that $C$ storing in soil is mainly the effect of new $C$ integration by the microbial community [58] and that the dehydrogenase activity is strictly related to microbial biomass and not only to total organic matter content [60]. It is reasonable to hypothesize the conditions of our experiment were not enough to cause an increase of dehydrogenase activity in two years, although data on FDA indicates that organic managements were able to increase the microbial community.

Phosphodiesterase and phosphomonoesterase activities are known to act sequentially in soil. It has been reported that the lower activity of phosphodiesterases than acid and alkaline phosphomonoesterase causes the production of $\mathrm{P}$ monoesters from $\mathrm{P}$ diesters that may stimulate the microbial synthesis of more phosphomonoesterases [61]. This conclusion seems in agreement with our data where phosphomonoesterase shows an activity up to four times higher than phosphodiesterase. Phosphodiesterase activity is significantly higher in organic managements characterized by light tillage than in conventional tillage which is consistent with previous trials that reported a higher phosphodiesterase activity in light tillage + mulching than in conventional and no tillage [59,60,62]. Phosphodiesterase activity was in average higher in 2009 than in 2008: due to the stable OC content, the main cause of this increase could be the rotation and in particular the combination cropassociated legume. The clover-garlic (CG) combination resulted in the highest values in summer among all managements and within the Org SGR $+C$ thesis, this combination gave always the highest results. The presence of garlic seems to be correlated with higher phosphodiesterase activity in Org SCG also when not associated with clover. The positive action of garlic root exudates was reported also in short-term continuous cropping (510 years) characterized by a significant increase in bacteria, fungi, phosphatase, and urease activity in the rhizosphere [63]. A positive effect on soil enzyme activities of garlic was also reported by Zhou at al. [64] for soil urease activity; Wang et al. [65] for urease and alkaline phosphatase activities. Yiang et al. [66] reported that garlic increased soil enzymatic activities and fungi populations also when rotated with watermelon. In both summer 2008 and 2009, the phosphodiesterase activity (Table 7), although without statistic evidence, seems to be higher in theses managed with legumes than in those organic theses without clover and pea: this is consistent with [67] who found that nodulated legumes species growing in savanna soils stimulated the acid phosphatase activity of the rhizosphere soil.

Although, phosphodiesterase and phosphomonoesterase act sequentially [52], when comparing the same period within the two years of experiment, we found phosphodiesterase increased in 2009, while phosphomonoesterase decreased (Table 10). We hypothesize the soil was enriched in organic and inorganic $P$ through the years, causing a decrease of phosphomonoesterase activity. This is in agreement with Kandeler et al. [68] who found an inverse correlation between the phosphomonoesterase activity and the P organic content of the rhizosphere soil sampled from Triticum aestivum and Trifolium alexandrium.

Protease activity evidenced a decrease from 2008 to 2009 except for the march datapoint (Table 8), with the higher values in July 2008 and July 2009 when samples were collected during fertilizers addition and higher temperatures: the sudden increase in $\mathrm{C}$ and $\mathrm{N}$ availability could have increased the microbial community growth rate with a consequent higher need of N. As reported by Geisseler and Horwath [69], the level of protease synthesis is determined by the need for $\mathrm{C}$ rather than $\mathrm{N}$ : this could be in agreement with OC decrease during the experiment.

Urease activity followed the same trend of protease (Table 8): most authors, see for example [70], found an increase of urease activity correlated with zero/light tillage and the consequent increase of organic matter as confirmed in the present work on comparison with conventionally managed soils. For the year-to-year trend among the organic samples, we hypothesize, like for protease, a disbalance in $\mathrm{C}$ and $\mathrm{N}$ content. However, it is interesting 
to note that, although not significant, urease activity is higher in bare soil when compared with same soil covered by crop (Table 9 ).

The canonical discriminant analysis successfully discriminates conventionally managed soils and organic managed theses. This is in line with the known action of organic management in soil activities [71]. The analysis also distinguishes Org SGR and Org SGR $+\mathrm{C}$ from Org PBF treatments with or without pea intercropping and/or associated crop. This confirms the importance of the crops in determining the overall soil quality. Present results indicate that garlic plays an important role in these phenomena in association with the presence of leguminous crop as clover. Not all the factors were equally important in the CDA algorithm (Figure 1, Table A1); this is in agreement with our analysis: indeed phosphodiesterase, phosphomonoesterase, and $\beta$-glucosidase gave the main contribution in separating the 4 clusters. In particular, the two phosphatases showed the main role in separating groups being the two enzymes apparently not dependent on $\mathrm{C}$ content decrease/stability, probably due to the priority to store P to build ATP.

\section{Conclusions}

In a sandy loamy soil, characterized by low OC content, organic management, coupled with minimum tillage, maintained a higher level of biological activity in comparison with conventional farming systems. Due to the short-term period of the experiment, the main physical parameters depending on organic matter content, like bulk density, did not significantly change. In contrast, the soil aggregate stability seemed affected by the quantity and quality of organic matter, suggesting that tested OF systems are promising for improvements of soil physical fertility in the long-term.

Crop rotation and the association with a legume gave the higher contribution in enhancing the biological activity in soil increasing "phosphatase mechanism" as a main biological source of energy. Garlic showed the best results in term of phosphatases activity.

Microbial phosphomonoesterases are probably the major contributing enzymes to the measured enzyme activity in soil $[72,73]$. This work suggests that the right choice of an effective rotation with the right crop species is fundamental to re-start biological activity in impoverished soil or to rapidly ameliorate its structure. Finally, from a methodological point of view, this work confirms the pivotal role played by the enzymatic indexes for monitoring the effects of management systems, being sensitive soil attributes that reflect the capacity of a soil to function and can be used as indicators of soil quality also in the short term.

Author Contributions: Conceptualization, P.C., F.C. and F.M.; Analysis P.C., N.D.F.; data curation, M.P.; writing — original draft preparation M.P.; writing—reviewing and editing P.C., N.D.F., F.C., F.M.; supervision P.C., F.M.; funding acquisition F.C., P.C., F.M. All authors have read and agreed to the published version of the manuscript.

Funding: This research was funded by VENETO AGRICOLTURA—Agenzia Veneta per l'Innovazione nel Settore Primario-and conducted by the Horticultural Experimental Centre 'Po di Tramontana', Rosolina (RO), Italy. PC was financially supported by the University of Padova DOR2072992/20.

Institutional Review Board Statement: Not applicable.

Informed Consent Statement: Not applicable.

Data Availability Statement: Not applicable.

Acknowledgments: The authors are grateful to Luca Conte for the help in conceiving the experiment. The authors also thank Francesco Barbi, Chiara Vivian, Nicolò Avogaro and Gioia Scarpa for their valuable help during soil sampling operations.

Conflicts of Interest: The authors declare no conflict of interest. 


\section{Appendix A}

Table A1. Mahalanobis quadratic distances.

\begin{tabular}{cccccc}
\hline \multicolumn{7}{c}{ Mahalanobis Distances } \\
\hline Managements & Org SGR + C & Org SGR & Org PBF + P & Org PBF & Conv WR \\
\hline Org SGR + C & 0 & 34.67 & 7.91 & 12.60 & 55.09 \\
Org SGR & 34.67 & 0 & 10.23 & 7.82 & 15.41 \\
Org PBF + P & 7.91 & 10.23 & 0 & 2.28 & 26.64 \\
Org PBF & 12.60 & 7.82 & 2.28 & 0 & 17.92 \\
Conv WR & 55.09 & 15.41 & 26.64 & 17.92 & 0 \\
\hline \multicolumn{7}{c}{ Significance of Mahalanobis Distances } \\
\hline Org SGR & Org PBF + P & Org PBF & Conv WR \\
\hline Org SGR + C & 1.000 & $<0.0001$ & 0.0001 & $<0.0001$ & $<0.0001$ \\
Org SGR & $<0.0001$ & 1.000 & $<0.0001$ & 0.0001 & $<0.0001$ \\
Org PBF + P & 0.0001 & $<0.0001$ & 1.000 & 0.073 & $<0.0001$ \\
Org PBF & $<0.0001$ & 0.0001 & 0.073 & 1.000 & $<0.0001$ \\
Conv WR & $<0.0001$ & $<0.0001$ & $<0.0001$ & $<0.0001$ & 1.000 \\
\hline
\end{tabular}

Table A2. Pearson correlation coefficients.

\begin{tabular}{ccccc}
\hline Factors & \multicolumn{2}{c}{ CAN 1 } & \multicolumn{2}{c}{ CAN 2 } \\
\hline & Pearson Cor. & $p$ & Pearson Cor. & $p$ \\
\hline$\beta$-Glucosidase & 0.89991 & $<0.0001$ & 0.13598 & 0.458 \\
Phosphomonoesterase & 0.69523 & $<0.0001$ & 0.42232 & 0.016 \\
HC & 0.62265 & 0.0001 & 0.56273 & 0.0008 \\
Phosphodiesterase & 0.66125 & $<0.0001$ & 0.46454 & 0.0074 \\
ASA & 0.55407 & 0.001 & 0.49636 & 0.0039 \\
Average bulk density & -0.13675 & 0.4555 & -0.27578 & 0.1266 \\
\hline
\end{tabular}

\section{References}

1. Godfray, H.C.J.; Garnett, T. Food security and sustainable intensification. Philos. Trans. R. Soc. B Biol. Sci. 2014, $369,20120273$. [CrossRef]

2. Lal, R. Soil carbon sequestration to mitigate climate change. Geoderma 2004, 123, 1-22. [CrossRef]

3. Barao, L.; Alaoui, A.; Ferreira, C.; Basch, G.; Schwilch, G.; Geissen, V.; Sukkel, W.; Lemesle, J.; Garcia-Orenes, F.; MoruganCoronado, A.; et al. Assessment of promising agricultural management practices. Sci. Total Environ. 2019, 649, 610-619. [CrossRef]

4. FAO; ITPS. Status of the World's Soil Resources (SWSR)-Main Report; Food and Agriculture Organization of the United Nations: Rome, Italy; Intergovernmental Technical Panel on Soils: Rome, Italy, 2015.

5. Stockdale, E.A.; Shepherd, M.A.; Fortune, S.; Cuttle, S.P. Soil fertility in organic farming systems-fundamentally different? Soil Use Manag. 2002, 18, 301-308. [CrossRef]

6. A European Green Deal I Euopena Commission. Available online: https:/ / ec.europa.eu/info/strategy/priorities-2019-2024/ european-green-deal_en (accessed on 25 March 2021).

7. Watson, C.A.; Atkinson, D.; Gosling, P.; Jackson, L.R.; Rayns, F.W. Managing soil fertility in organic farming systems. Soil Use Manag. 2002, 18, 239-247. [CrossRef]

8. Monokrousos, N.; Papatheodorou, E.M.; Stamou, G.P. The response of soil biochemical variables to organic and conventional cultivation of Asparagus sp. Soil Biol. Biochem. 2008, 40, 198-206. [CrossRef]

9. Lal, R. Challenges and opportunities in soil organic matter research. Eur. J. Soil Sci. 2009, 60, 158-169. [CrossRef]

10. Tu, C.; Ristaino, J.B.; Hu, S.J. Soil microbial biomass and activity in organic tomato farming systems: Effects of organic inputs and straw mulching. Soil Biol. Biochem. 2006, 38, 247-255. [CrossRef]

11. Six, J.; Paustian, K. Aggregate-associated soil organic matter as an ecosystem property and a measurement tool. Soil Biol. Biochem. 2014, 68, A4-A9. [CrossRef]

12. Le Bissonnais, Y. Aggregate stability and assessment of soil crustability and erodibility: I. Theory and methodology. Eur. J. Soil Sci. 1996, 47, 425-437. [CrossRef] 
13. Dal Ferro, N.; Berti, A.; Francioso, O.; Ferrari, E.; Matthews, G.P.; Morari, F. Investigating the effects of wettability and pore size distribution on aggregate stability: The role of soil organic matter and the humic fraction. Eur. J. Soil Sci. 2012, 63, 152-164. [CrossRef]

14. Bachmann, J.; Guggenberger, G.; Baumgartl, T.; Ellerbrock, R.H.; Urbanek, E.; Goebel, M.-O.; Kaiser, K.; Horn, R.; Fischer, W.R. Physical carbon-sequestration mechanisms under special consideration of soil wettability. J. Plant Nutr. Soil Sci. 2008, 171, 14-26. [CrossRef]

15. Singh, G.; Bhattacharyya, R.; Das, T.K.; Sharma, A.R.; Ghosh, A.; Das, S.; Jha, P. Crop rotation and residue management effects on soil enzyme activities, glomalin and aggregate stability under zero tillage in the Indo-Gangetic Plains. Soil Tillage Res. 2018, 184, 291-300. [CrossRef]

16. Renella, G.; Szukics, U.; Landi, L.; Nannipieri, P. Quantitative assessment of hydrolase production and persistence in soil. Biol. Fertil. Soils 2007, 44, 321-329. [CrossRef]

17. Gil-Sotres, F.; Trasar-Cepeda, C.; Leiros, M.C.; Seoane, S. Different approaches to evaluating soil quality using biochemical properties. Soil Biol. Biochem. 2005, 37, 877-887. [CrossRef]

18. Riffaldi, R.; Saviozzi, A.; Levi-Minzi, R.; Cardelli, R. Biochemical properties of a Mediterranean soil as affected by long-term crop management systems. Soil Tillage Res. 2002, 67, 109-114. [CrossRef]

19. Marinari, S.; Mancinelli, R.; Carnpiglia, E.; Grego, S. Chemical and biological indicators of soil quality in organic and conventional farming systems in Central Italy. Ecol. Indic. 2006, 6, 701-711. [CrossRef]

20. Grayston, S.J.; Wang, S.Q.; Campbell, C.D.; Edwards, A.C. Selective influence of plant species on microbial diversity in the rhizosphere. Soil Biol. Biochem. 1998, 30, 369-378. [CrossRef]

21. Miller, H.J.; Henken, G.; Vanveen, J.A. Variation and composition of bacterial-populations in the rhizospheres of maize, wheat, and grass cultivars. Can. J. Microbiol. 1989, 35, 656-660. [CrossRef]

22. Houlden, A.; Timms-Wilson, T.M.; Day, M.J.; Bailey, M.J. Influence of plant developmental stage on microbial community structure and activity in the rhizosphere of three field crops. FEMS Microbiol. Ecol. 2008, 65, 193-201. [CrossRef]

23. Bünemann, E.K.; Bongiorno, G.; Bai, Z.; Creamer, R.E.; De Deyn, G.; de Goede, R.; Fleskens, L.; Geissen, V.; Kuyper, T.W.; Mäder, P.; et al. Soil quality-A critical review. Soil Biol. Bio-Chem. 2018, 120, 105-125. [CrossRef]

24. Barbi, A.; Cagnati, A.; Cola, G.; Checchetto, F.; Chiaudani, A.; Crepaz, A.; Delillo, I.; Mariani, L.; Marigo, G.; Meneghin, P.; et al. Atlante Climatico del Veneto; Regione del Veneto: Mestre, Italy, 2013.

25. IUSS Working Group WRB. World Reference Base for Soil Resources 2014, Update 2015 International Soil Classification System for Naming Soils and Creating Legends for Soil Maps; World Soil Resources Reports No. 106; FAO: Rome, Italy, 2015.

26. Sibbesen, E.; Skjøth, F.; Rubæk, G.H. Tillage caused dispersion of phosphorus and soil in four 16-year old field experiments. Soil Tillage Res. 2000, 54, 91-100. [CrossRef]

27. Grossman, R.B.; Reinsch, T.G. Bulk Density and Linear Extensibility. In Methods of Soil Analysis: Physical Methods, Part 4; Dane, J.H., Topp, G.C., Eds.; Soil Science Society of America: Madison, WI, USA, 2002; pp. 201-228.

28. Sitzia, T.; Pizzeghello, D.; Dainese, M.; Ertani, A.; Carletti, P.; Semenzato, P.; Nardi, S.; Cattaneo, D. Topsoil organic matter properties in contrasted hedgerow vegetation types. Plant Soil 2014. [CrossRef]

29. Sumner, M.; Miller, W. Cation exchange capacity, and exchange coefficients. In Methods of soil Analysis. Part 2: Chemical Properties, 3rd ed.; Sparks, D., Ed.; Soil Science Society of America: Madison, WI, USA, 1996; pp. 1201-1229.

30. Olsen, S.; Sommers, L.E. Phosphorus. In Methods of Soil Analysis. Part 2; Page, A., Miller, R., Keeney, D., Eds.; American Society of Agronomy: Madison, WI, USA, 1982; pp. 421-422.

31. FAO. Standard operating procedure for soil calcium carbonate equivalent. In Volumetric Calcimeter Method; FAO: Rome, Italy, 2020.

32. Walkley, A.; Black, I.A. An examination of Degtjareff method for determining soil organic matter and a proposed modification of the chromic acid titration method. Soil Sci. 1934, 37, 29-38. [CrossRef]

33. USDA-NRCS United States. Department of Agriculture-Natural Resources Conservation Service, Soil Survey Laboratory Methods Manual; Version No. 4.0; Soil Survey Investigations Report No. 42 (2004); USDA-NRCS: Lincoln, NE, USA, 2004.

34. Cardinali, A.; Carletti, P.; Nardi, S.; Zanin, G. Design of riparian buffer strips affects soil quality parameters. Appl. Soil Ecol. 2014, 80, 67-76. [CrossRef]

35. Kandeler, E.; Gerber, H. Short-term assay of soil urease activity using colorimetric determination of ammonium. Biol. Fertil. Soils 1988, 6, 68-72. [CrossRef]

36. Nannipieri, P.; Kandeler, E.; Ruggiero, P. Enzyme activities and microbiological and biochemical processes in soil. In Enzymes in the Environment; Burns, R.G., Dick, R.P., Eds.; Marcel Dekker: New York, NY, USA, 2002; pp. 1-34.

37. Masciandaro, G.; Ceccanti, B.; Ronchi, V.; Bauer, C. Kinetic parameters of dehydrogenase in the assessment of the response of soil to vermicompost and inorganic fertilisers. Biol. Fertil. Soils 2000, 32, 479-483. [CrossRef]

38. Browman, M.G.; Tabatabai, M.A. Phosphodiesterase Activity of Soils. Soil Sci. Soc. Am. J. 1978, 42, 284-290. [CrossRef]

39. Eivazi, F.; Tabatabai, M.A. Glucosidases and galactosidases in soils. Soil Biol. Biochem. 1988, 20, 601-606. [CrossRef]

40. Adam, G.; Duncan, H. Development of a sensitive and rapid method for the measurement of total microbial activity using fluorescein diacetate (FDA) in a range of soils. Soil Biol. Biochem. 2001, 33, 943-951. [CrossRef]

41. Douglas, J.T.; Goss, M.J. Stability and organic matter content of surface soil aggregates under different methods of cultivation and in grassland. Soil Tillage Res. 1982, 2, 155-175. [CrossRef] 
42. Bocchi, S.; Confalonieri, R.; Frigeni, S.; Morari, F.; Patruno, A. Wet Aggregate Stability Index: Precision assessment of Tiulin method through an inter-laboratory test. Agrochimica 2008, 52, 71-82.

43. Henin, S.; Monnier, G.; Combeau, A. Methode pour l'etude de la stabilitè structurale des sols. Ann. Agron. 1958, 9, 73-92.

44. Field, A. Discovering Statistics Using SPSS, 2nd ed.; SAGE Publications Ltd.: London, UK, 2005.

45. Dal Ferro, N.; Quinn, C.; Morari, F. A Bayesian belief network framework to predict SOC dynamics of alternative management scenarios. Soil Tillage Res. 2018, 179, 114-124. [CrossRef]

46. Camarotto, C.; Piccoli, I.; Dal Ferro, N.; Polese, R.; Chiarini, F.; Furlan, L.; Morari, F. Have we reached the turning point? Looking for evidence of SOC increase under conservation agriculture and cover crop practices. Eur. J. Soil Sci. 2020. [CrossRef]

47. Dal Ferro, N.; Piccoli, I.; Berti, A.; Polese, R.; Morari, F. Organic carbon storage potential in deep agricultural soil layers: Evidence from long-term experiments in northeast Italy. Agric. Ecosyst. Environ. 2020, 300, 106967. [CrossRef]

48. Koch, H.-J.; Stockfisch, N. Loss of soil organic matter upon ploughing under a loess soil after several years of conservation tillage. Soil Tillage Res. 2006, 86, 73-83. [CrossRef]

49. VandenBygaart, A.J.; Kay, B.D. Persistence of Soil Organic Carbon after Plowing a Long-Term No-Till Field in Southern Ontario, Canada. Soil Sci. Soc. Am. J. 2004, 68, 1394-1402. [CrossRef]

50. Six, J.; Conant, R.T.; Paul, E.A.; Paustian, K. Stabilization mechanisms of soil organic matter: Implications for C-saturation of soils. Plant Soil 2002, 241, 155-176. [CrossRef]

51. An, S.; Mentler, A.; Mayer, H.; Blum, W.E.H. Soil aggregation, aggregate stability, organic carbon and nitrogen in different soil aggregate fractions under forest and shrub vegetation on the Loess Plateau, China. CATENA 2010, 81, 226-233. [CrossRef]

52. Le Bissonnais, Y.; Arrouays, D. Aggregate stability and assessment of soil crustability and erodibility: II. Application to humic loamy soils with various organic carbon contents. Eur. J. Soil Sci. 1997, 48, 39-48. [CrossRef]

53. Piccoli, I.; Camarotto, C.; Lazzaro, B.; Furlan, L.; Morari, F. Conservation Agriculture Had a Poor Impact on the Soil Porosity of Veneto Low-lying Plain Silty Soils after a 5-year Transition Period. Land Degrad. Dev. 2017, 28, 2039-2050. [CrossRef]

54. Patle, P.N.; Navnage, N.P.; Barange, P.K. Fluorescein Diacetate (FDA): Measure of Total Microbial Activity and as Indicator of Soil Quality. Int. J. Curr. Microbiol. Appl. Sci. 2018, 7, 2103-2107. [CrossRef]

55. Lupwayi, N.Z.; Larney, F.J.; Blackshaw, R.E.; Kanashiro, D.A.; Pearson, D.C. Phospholipid fatty acid biomarkers show positive soil microbial community responses to conservation soil management of irrigated crop rotations. Soil Tillage Res. 2017, 168, 1-10. [CrossRef]

56. Muscolo, A.; Settineri, G.; Attinà, E. Early warning indicators of changes in soil ecosystem functioning. Ecol. Indic. 2015, 48, 542-549. [CrossRef]

57. Weerasekara, C.S.; Udawatta, R.P.; Gantzer, C.J.; Kremer, R.J.; Jose, S.; Veum, K.S. Effects of Cover Crops on Soil Quality: Selected Chemical and Biological Parameters. Commun. Soil Sci. Plant. Anal. 2017, 48, 2074-2082. [CrossRef]

58. Lange, M.; Eisenhauer, N.; Sierra, C.A.; Bessler, H.; Engels, C.; Griffiths, R.I.; Mellado-Vazquez, P.G.; Malik, A.A.; Roy, J.; Scheu, S.; et al. Plant diversity increases soil microbial activity and soil carbon storage. Nat. Commun. 2015, 6, 6707. [CrossRef]

59. Chu, H.; Lin, X.; Fujii, T.; Morimoto, S.; Yagi, K.; Hu, J.; Zhang, J. Soil microbial biomass, dehydrogenase activity, bacterial community structure in response to long-term fertilizer management. Soil Biol. Biochem. 2007, 39, 2971-2976. [CrossRef]

60. Garcia, C.; Hernandez, T.; Costa, F. Potential use of dehydrogenase activity as an index of microbial activity in degraded soils. Commun. Soil Sci. Plant. Anal. 1997, 28, 123-134. [CrossRef]

61. Nannipieri, P.; Giagnoni, L.; Landi, L.; Renella, G. Role of Phosphatase Enzymes in Soil. In Phosphorus in Action; Springer: Berlin/Heidelberg, Germany, 2011; pp. 215-243. [CrossRef]

62. Deng, S.P.; Tabatabai, M.A. Effect of tillage and residue management on enzyme activities in soils. 3. Phosphatases and arylsulfatase. Biol. Fertil. Soils 1997, 24, 141-146. [CrossRef]

63. Liu, S.; Liu, S.; Zhang, Z.; Wei, H.; Qi, J.; Duan, J. Influence of garlic continuous cropping on rhizosphere soil microorganisms and enzyme activities. Sci. Agric. Sin. 2010, 43, 1000-1006.

64. Zhou, X.; Yu, G.; Wu, F. Effects of intercropping cucumber with onion or garlic on soil enzyme activities, microbial communities and cucumber yield. Eur. J. Soil Biol. 2011, 47, 279-287. [CrossRef]

65. Wang, M.; Wu, C.; Cheng, Z.; Meng, H.; Zhang, M.; Zhang, H. Soil chemical property changes in eggplant/garlic relay intercropping systems under continuous cropping. PLoS ONE 2014, 9, e111040. [CrossRef]

66. Yang, R.; Mo, Y.; Liu, C.; Wang, Y.; Ma, J.; Zhang, Y.; Li, H.; Zhang, X. The Effects of Cattle Manure and Garlic Rotation on Soil under Continuous Cropping of Watermelon (Citrullus lanatus L.). PLoS ONE 2016, 11, e0156515. [CrossRef]

67. Izaguirre-Mayoral, M.L.; Flores, S.; Carballo, O. Determination of acid phosphatase and dehydrogenase activities in the rhizosphere of nodulated legume species native to two contrasting savanna sites in Venezuela. Biol. Fertil. Soils 2002, 35, 470-472. [CrossRef]

68. Kandeler, E.; Marschner, P.; Tscherko, D.; Gahoonia, T.S.; Nielsen, N.E. Microbial community composition and functional diversity in the rhizosphere of maize. Plant. Soil 2002, 238, 301-312. [CrossRef]

69. Geisseler, D.; Horwath, W. Regulation of extracellular protease activity in soil in response to different sources and concentrations of nitrogen and carbon. Soil Biol. Biochem. 2008, 40, 3040-3048. [CrossRef]

70. Deng, S.P.; Tabatabai, M.A. Effect of tillage and residue management on enzyme activities in soils. 1. Amidohydrolases. Biol. Fertil. Soils 1996, 22, 202-207. [CrossRef]

71. Tully, K.L.; McAskill, C. Promoting soil health in organically managed systems: A review. Org. Agric. 2020, 10, 339-358. [CrossRef] 
72. Renella, G.; Egamberdiyeva, D.; Landi, L.; Mench, M.; Nannipieri, P. Microbial activity and hydrolase activities during decomposition of root exudates released by an artificial root surface in Cd-contaminated soils. Soil Biol. Biochem. 2006, 38, 702-708. [CrossRef]

73. Renella, G.; Landi, L.; Valori, F.; Nannipieri, P. Microbial and hydrolase activity after release of low molecular weight organic compounds by a model root surface in a clayey and a sandy soil. Appl. Soil Ecol. 2007, 36, 124-129. [CrossRef] 